Georgetown University Law Center

Scholarship @ GEORGETOWN LAW

2021

\title{
The Corruption of Copyright and Returning It to Its Original Purposes
}

Michelle M. Wu

Georgetown University Law Center, mmw84@law.georgetown.edu

This paper can be downloaded free of charge from:

https://scholarship.law.georgetown.edu/facpub/2410

https://ssrn.com/abstract=3892269

Legal Reference Services Quarterly, published online August 24, 2021.

This open-access article is brought to you by the Georgetown Law Library. Posted with permission of the author. Follow this and additional works at: https://scholarship.law.georgetown.edu/facpub

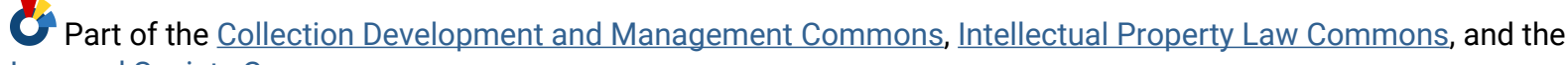
Law and Society Commons 
This is the pre-publication draft. The published version can be found in LEGAL REFERENCE

SERVICES QUARTERLY at

https://www.tandfonline.com/doi/full/10.1080/0270319X.2021.1966238

\title{
The Corruption of Copyright and Returning It to Its Original Purposes
}

\author{
Michelle M. Wu ${ }^{1}$
}

\section{Contents}

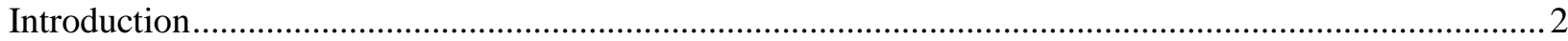

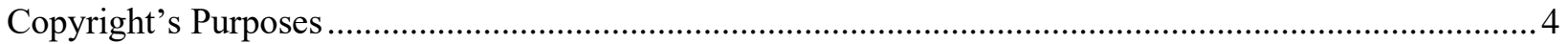

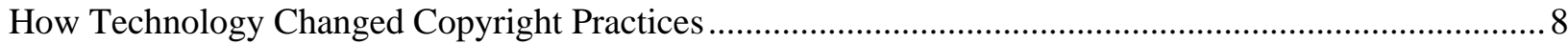

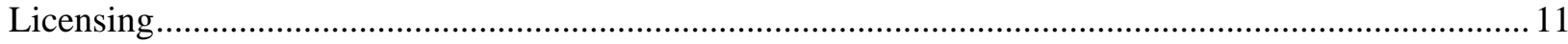

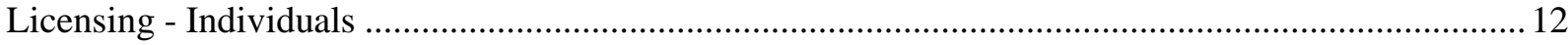

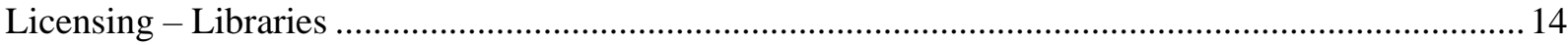

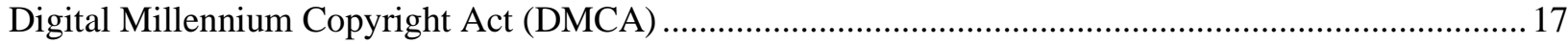

Industry Conglomerates' Interests Overtaking Author and Public Interests...........................................20

Diminishing Copyright's Private Interest (Author Revenue) ….........................................................20

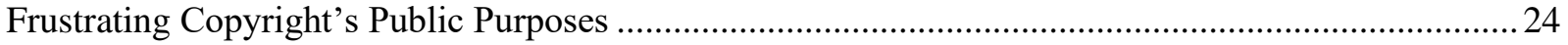

Preventing Reasonable Uses of Licensed/Purchased Materials ....................................................25

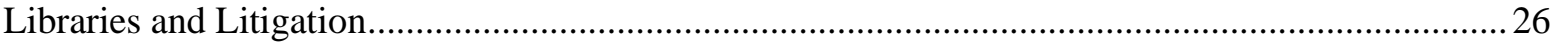

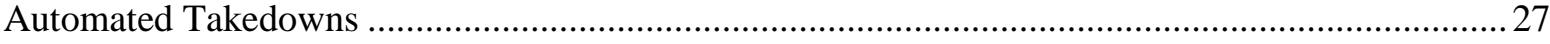

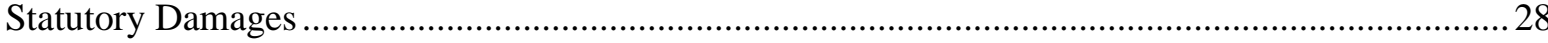

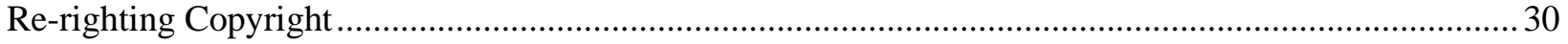

Replace Statutory Damages ......................................................................................................... 30

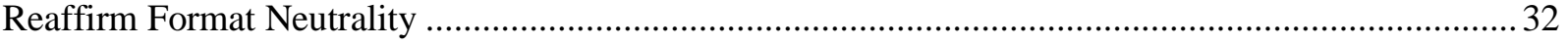

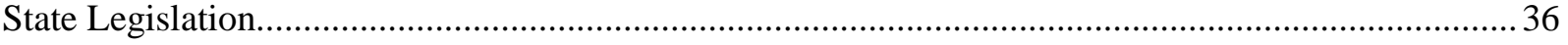

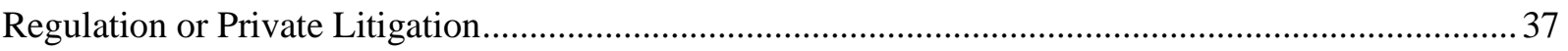

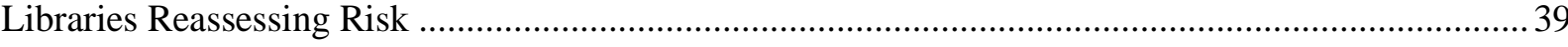

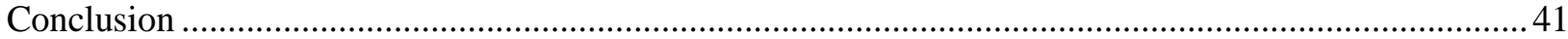

\footnotetext{
${ }^{1}$ Retired law library director and professor of law. Formerly the law library director at Georgetown University Law Center, Hofstra Law School, and the University of Houston Law School, and a professor of law at Georgetown University Law Center and Hofstra Law School.
} 


\section{Introduction}

[the United States Congress shall have power] To promote the Progress of Science and useful Arts, by securing for limited Times to Authors and Inventors the exclusive Right to their respective Writings and Discoveries. ${ }^{2}$

As enshrined in the Constitution, copyright in the United States has a singular, animating purpose: to promote the progress of science and the useful arts. In order to accomplish that objective, Congress was empowered to establish a limited monopoly in the form of a term of protection during which the author held certain exclusive rights, such as reproduction and distribution, over that work. These two interests - that of the public and of the author - serve as the backbone of copyright law.

Within the last two decades, though, some industries have systematically undermined both of those interests, redirecting the benefits of copyright towards themselves instead of the intended beneficiaries: creators and the public. In examining how copyright has been flipped against its purposes, this paper will largely focus on book, movie, and music publishing, as these are the ones with business models that make them most susceptible to the abuses described. ${ }^{3}$ While the spotlighted industry actors may not represent the majority of entities in their respective fields, they happen to be the ones with the greatest power, wealth, and influence, which means that the impact of their actions is widespread and outsized. This power element makes their redirection of copyright all the more troubling, as it benefits the already-privileged few over the public and the majority of creators.

That central premise of this paper --- that copyright benefits the privileged and has been used to suppress the uses it was intended to foster --- is not entirely new. It served as one of the core disputes over the Copyright Term Extension Act (CTEA), where opposition to extending copyright's term was diverse, coming from authors, economists, academics, historians, medical professionals, non-profits, technology industry actors (e.g., Intel), and downstream-use for-profit enterprises (e.g., film restorer). ${ }^{4}$ Significant statistical evidence already existed at that time demonstrating that very few would benefit from such an extension while many would be harmed

\footnotetext{
${ }^{2}$ U.S. CONST. art. I, $\S 8$, cl. 8 .

${ }^{3}$ These are the industries that rely heavily on individual use for profit. Other copyright industries --- dramatic works, dance, art - make more income on broader uses, such as performance or display. The only other industry that has similar characteristics is the computer gaming industry, but it has been excluded is because of the unique nature of the industry, which is interactive and iterative.

${ }^{4}$ Among the entities submitting briefs in Eldred v. Ashcroft (537 U.S. 186 (2003)) against the CTEA were: the Association of American Physicians \& Surgeons, National Humanities Alliance, Free Software Foundation, Hal Roach Studios, Intel, the Organization of American Historians, the Internet Archive, and the Cato Institute. Numerous economists, professors, and other individuals also filed briefs noting similar concerns.
} 
by it, ${ }^{5}$ and it was commonly known that a few powerful, wealthy interests were driving the legislation ${ }^{6}$.

What makes the issue in this case different is that the CTEA was an act of Congress, a deliberate decision by a governing body to place a small number of private interests over others. Whether the decision was based on sound reasoning or not, Congress was acting within its authority and it was on that basis that the Supreme Court ultimately upheld the legislation. ${ }^{7}$ In contrast, most recent actions have been undertaken by private corporate actors in a manner that arguably changes the meaning of copyright in a manner that infringes on Congress' authority in determining copyright's purpose.

These actions include using technological controls or automation to preemptively cut off fair uses, engaging in intimidation practices to thwart innovation or public use, implementing automated takedowns, replacing ownership with rental, and limiting traditional pathways to information for the poor. Each of these practices depresses innovation and fair uses, interfering with the public purpose of copyright while also (in some cases) closing revenue opportunities for authors, thereby frustrating the private purpose of copyright as well.

This article seeks to provide a brief historical overview of the motivations behind the Copyright Clause, examine how technology has been used to unbalance copyright, analyze how these changes negatively impact innovation and the public interest, and consider paths forward.

In this paper, the term "book" will be used as short-hand for all literary works excluding computer programs, and the term "industry conglomerates" will stand for publishing entities + the Authors Guild. The Authors Guild is included in this last category despite its representation of authors because of its history of aligning itself with large-publisher interests. It represents less than $5 \%$ of all United States authors, ${ }^{8}$ and by no means serves as an accurate reflection for all

\footnotetext{
${ }^{5}$ Even as early as 1909 , successful authors acknowledged in testimony that few authors would benefit from long copyright terms ("One author per year produces a book which can outlive the forty-two year limit, and that is all. This nation can not produce two authors per year who can create a book that will outlast forty-two years.") To Amend and Consolidate the Acts Respecting Copyright: Hearing on S. 6330 and H.R. 19853 Before the S. Comm. on Patents and the H. Comm. on Patents, conjointly, 59th Cong. 117 (1906) (testimony of Samuel L. Clemens). See also EDWARD RAPPAPORT, CONG. RESEARCH SERV., 98-144 E, COPYRIGHT TERM EXTENSION: ESTIMATING THE ECONOMIC VALUES 5-15 (1998). Based on a sampling of each type of work, he determined that approximately $3.8 \%$ of books and 3.6\% of music lost commercial viability each year, and movies had more variable rates, with percentages changing drastically based on the era in which a movie was produced; Brief of George A. Akerlof et al. as Amici Curiae in Support of Petitioners at 2, Eldred v. Ashcroft, 537 U.S. 186 (2003) (No. 01-618).

${ }^{6}$ See Arlen W. Langvardt \& Kyle T. Langvardt, Unwise or Unconstitutional?: The Copyright Term Extension Act, the Eldred Decision, and the Freezing of the Public Domain for Private Benefit, 5 MinN. InTELL. Prop. REV. 193 (2004); Phil Galdston \& David Wolfert, The Music Modernization Act Misses the Mark, VARIETY (Mar. 16, 2018), https://variety.com/2018/biz/news/the-music-modernization-act-misses-the-mark-guest-column-1202728994/; Jillian J. Dahrooge, The Real Slim Shady: How Spotify and Other Music Streaming Services Are Taking Advantage of the Loopholes Within the Music Modernization Act, 21 J. HIGH TECH. L. 199, 236-8 (2021).

${ }^{7}$ Eldred v. Ashcroft, 537 U.S. 186 (2003).

${ }^{8}$ According to its annual report, the Authors Guild has 6,144 members. THE AUTHORS GUILD, AUTHORS GUILD ANNUAL REPORT FOR 2020, at 11 (2020), https://www.authorsguild.org/wp-
} 
authors' interests, as has been evidenced by opposing positions taken by other author groups (e.g., Authors Alliance).

\section{Copyright's Purposes}

At its heart, copyright serves two interests, the private interest of an author being compensated for the creation of her work and the public interests of information access, preservation, and innovation (the last in part through the availability of a public domain on which others can build). While other interests and purposes are served by copyright - providing revenue and employment to a growing number of industries, ${ }^{9}$ contributions to the nation's treasury in the form of taxes, ${ }^{10}$ and igniting imaginations, to name a few --- these two core purposes are the ones that justify copyright's existence at all. They are the two interests most commonly cited throughout history and which are featured prominently in any proposed change to the nation's copyright laws. To fully understand why copyright settled on these two interests, it is necessary to look at the environment in which copyright was born in the United States.

In colonial America, authors advocated fiercely for copyright laws distinctly different from the earlier iterations that protected primarily publishers, not authors. ${ }^{11}$ They were anxious to ensure their own livelihoods and reputations as well as to stop publishers from profiting from their works without just payment. ${ }^{12}$ After hearing from authors, the Continental Congress acknowledged the soundness of vesting exploitation rights of literary property in its author:

The committee ... to whom were referred sundry papers and memorials from different persons on the subject of literary property, [are] persuaded that nothing is more properly a man's own than the fruit of his study, and that the protection and security of literary property would greatly tend to encourage genius. ${ }^{13}$

\footnotetext{
content/uploads/2021/03/AuthorsGuild_AnnualReport_2021-final.pdf. The Bureau of Labor Statistics estimated the number of writer and author jobs in 2019 as 131,200. BUREAU OF LABOR STATISTICS, Writers and Authors, OCCUPATIONAL OUTLOOK HANDBOOK, https://www.bls.gov/ooh/media-and-communication/writers-andauthors.htm.

9 " [T] he core copyright industries of the United States-those industries whose primary purpose is to create, produce, distribute, or exhibit copyright materials-provide significant value added to U.S. gross domestic product (“GDP”); real growth which outpaces the rest of the economy; an increasing number of high-paying jobs; and substantial foreign sales and exports, surpassing many industry sectors." STEPHEN E. SIWEK, COPYRIGHT INDUSTRIES IN THE U.S. ECONOMY: THE 2018 REPORT 3 (December 2018), https://iipa.org/files/uploads/2018/12/2018CpyrtRptFull.pdf. ${ }^{10}$ Id. at 18 .

${ }^{11}$ Oren Bracha, The Ideology of Authorship Revisited: Authors, Markets, and Liberal Values in Early American Copyright, 118 YALE L.J. 186 (2008).

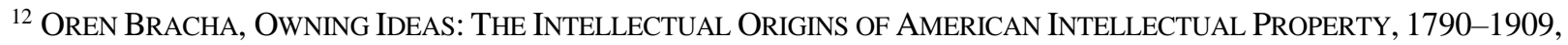
at 40 (2016). An image of the Joel Barlow letter referenced can be found here: http:// www.copyrighthistory.org/cam/tools/request/showRepresentation?id=representation_us_1783b.

1324 JOURNALS OF THE CONTINENTAL CONGRESS 326 (1783).
} 
and recommended that individual states enact copyright laws that provided authors or publishers least 14 years of protection for published works. ${ }^{14}$ All states except Delaware enacted such laws, though the terms varied, and most states chose to invest copyright in authors only, excluding the publishers from any explicit interest. ${ }^{15}$ In doing so, lawmakers appeared to recognize that vesting copyright in publishers would not meet the stated intention of supporting creators in making a living from their works. After all, there was already a long history of piracy by publishers, ${ }^{16}$ and giving them further rights would have simply encouraged acts designed to decrease rather than increase author income. By granting copyright to authors, states could at least provide authors with more leverage in initial negotiation with publishers.

The public interest served as a counterbalance to private rights and was as relevant to the copyright formulation as author ownership rights. ${ }^{17}$ Part of this interest was seen as complementary to authors' rights, as giving authors an economic right was thought to encourage the creation of new works. ${ }^{18}$ As each new work was seen as a new commodity (in the form of knowledge) for society, legislation to incentivize such creation was, therefore, in the public interest. ${ }^{19}$ In contrast, the other aspect of public interest was in direct opposition to the private interest. It was the need for an informed citizenry, made possible only through widespread information dissemination, an essential goal if a democracy were ever to function well. Correspondence among the Founders illustrated the awareness of the contradictions in purpose:

\footnotetext{
${ }^{14} I d$.

15 " [T] welve of the thirteen states (all except Delaware) had used the Statute of Anne as a model for enacting state copyright statutes during the period of the Confederation - from 1783 to 1786 - shortly before the Constitutional Convention in 1787." Lyman Ray Patterson, Understanding the Copyright Clause, 47 J. COPYRIGHT SOC'Y U.S.A. 365, 374 (2000)

${ }^{16}$ Bodo Balazs, Coda: A Short History of Book Piracy, in MEDIA PIRACY IN EMERGING ECONOMIES, Social Science Research Council 408-411 (Joe Karaganis ed., 2011). See also, Oren Bracha, United States copyright, 1672-1909, in RESEARCH HANDBOOK ON THE HISTORY OF COPYRIGHT LAW 335, 338-339 (Isabella Alexander \& H. Tomas Gomez-Arostegui eds., Edward Elgar Pub. 2016).

17 "These twenty-four words [of the Copyright Clause] contain three ideas fundamental to a free society and are used to limit the copyright power: copyright is not to be used for censorship (because copyright is to promote learning), the public domain (because copyright is limited to new works for a limited time), 7 and public access (because publication is a condition for statutory copyright)." Patterson, supra note 15 at 367-68 (2000).

18 "The economic philosophy behind the clause empowering Congress to grant patents and copyrights is the conviction that encouragement of individual effort by personal gain is the best way to advance public welfare through the talents of authors and inventors in 'Science and useful Arts.' " Mazer v. Stein, 347 U.S. 201, 219 (1954). See also Stewart E. Sterk, Rhetoric and Reality in Copyright Law, 94 MicH. L. ReV. 1197 (1996); Martha Woodmansee, On the Author Effect: Recovering Collectivity, in THE CONSTRUCTION OF AUTHORSHIP (Woodmansee \& Jaszi eds., Duke Univ. Pr. 1994) (noting that any work of authorship is a collaborative effort, building on others' work).

${ }^{19}$ See Hon. Richard A. Posner, Do We Have Too Many Intellectual Property Rights?, 9 MARQ. InTELL. Prop. L. REV. 173, 177 (2005). ("If you had a situation in which anyone was free to come along and harvest the crops that you had planted, you would not have any incentive to plant. If we want people to invest for the future, to we have to give them property rights.")
} 
Jefferson's writings reveal his deeply held view that a copyright monopoly posed a threat to the dissemination of creative works and knowledge to the public, although he also recognized that granting a copyright monopoly would incentivize the creation of copyrighted works. Jefferson's fears about the dangers of monopolies were shared by Madison, who was a driving force behind the inclusion of the Copyright Clause in the Constitution and was likely significantly responsible for its final wording. Madison thought it was vitally important to protect the value of the diffusion of knowledge by limiting the government's power to grant a copyright monopoly. Madison and Jefferson both agreed that this protection was a necessary prerequisite for effective republican self-government. ${ }^{20}$

While the Continental Congress did not explicitly include public interest concerns in its copyright recommendations, most of the states that adopted legislation, both before and after the recommendation, did. Massachusetts, for example, adopted a deposit requirement, and other states adopted language that signaled that the author's interest was valued only insofar as it met the purpose of being beneficial to the public. ${ }^{21}$ An example of this public orientation comes from New Hampshire's preamble to their early copyright laws:

\section{As the improvement of knowledge, the progress of civilization, and the advancement of human happiness, greatly depend on the efforts of ingenious persons in the various arts and sciences; as the principal encouragement such persons can have to make great and beneficial exertions of this nature, must consist in the legal security of the fruits of their study and industry to themselves; and as such security is one of the natural rights of all men, there being no property more peculiarly a man's own than that which is produced by the labour of his mind: Therefore, to encourage the publication of literary productions, honorary and beneficial to the public. ${ }^{22}$ (emphasis added)}

The Founders also adopted this public purpose in the drafting of the Copyright Clause in the Constitution. The language in the Constitution not only reflected the intended balance

\footnotetext{
${ }^{20}$ Susanna Frederick Fischer, Threatening the Founding Ideal of A Republic of Letters: An Assessment of the Supreme Court's Copyright Decisions over the First Decade of the Twenty-First Century, 5 AKRON INTELL. PROP. J. 205, 207 (2011).

${ }^{21}$ COPYRight EnACTMENTS OF THE UnITED STATES 1783-1906, at 11-31 (Thorvald Solberg ed., rev. 2d ed. 1906).

${ }^{22}$ WILliam F. PATRY, COPYRIGHT LAW AND PRACTICE 21 (2000), http://digital-law-online.info/patry/patry3.html (referencing the full text in COPYRIGHT OFFICE, LIBRARY OF CONGRESS, COPYRIGHT ENACTMENTS: LAWS PASSED IN THE UNITED STATES SinCE 1783 RELATING TO COPYRIGHT 8 (rev. ed. 1973).
} 
between the two interests, but its phrasing also made clear which of those interests should win out should there be a conflict. ${ }^{23}$ The purpose of copyright was the "progress of science and the useful arts." The private rights attendant to copyright were in service to that goal.

In practice, the tension between the stated interests was also evident from the start. The nation's residents were eager for news, educational writings, and reading materials, but it was costly and time consuming for publishers to obtain rights for all the materials desired. Publishers, therefore, relied heavily on unauthorized copies to meet readers' needs. ${ }^{24}$ The country's printing presses used much of what they needed without payment and viewed this activity as being natural and beneficial to their communities and their own survival. ${ }^{25}$ This strong interest from the reading public as well as commercial actors in unauthorized reproduction in turn led lawmakers to draft legislation that limited author protections with an eye towards keeping presses running and meeting its nation's informational needs. Unsurprisingly, then, the laws initially passed protected only United States' authors and then, once foreign authors gained protection, only works that were manufactured or printed in the country. ${ }^{26}$

In other words, when presented with a choice between the public interest and the author's, Congress acted in a manner consistent with the priority of rights expressed in the Copyright Clause. It protected the nation's interests first. The author's interest was secondary. As time progressed and the consequences of granting greater deference to one interest over the other became less stark, Congress extended protection to a greater number of works, a larger range of authors, and more uses.

While research has since shown that some of the assumptions behind the private interest purpose of the Copyright Clause and subsequent legislation were faulty, the principles themselves still meaningfully serve the purposes intended. For example, most authors clearly require no compensation as incentive to generate creative works, ${ }^{27}$ as illustrated in the

\footnotetext{
${ }^{23}$ RAY PATtERSON, COPYRIGHT IN HistoriCAl PERSPECTIVE 193 (1968).

${ }^{24}$ Hall et al., Practices of Reading, in A History OF THE BOOK IN AMERICA. VOlume 1: THE COLONIAL BOOK IN THE ATLANTIC WORLD, 377-410 (Hugh Amory \& David D. Hall eds., 2007) (describing reader interests and types of materials in demand); Spoo, infra note 25 (detailing the history of piracy in the early American history). ${ }^{25}$ Robert SpOO, Without Copyrights: PiRACY, PUblishing, AND THE PUBlic DomAin 20-21 (2013).

2635 Stat. 1075 (1909). See also The Manufacturing Clause: Copyright Protection to the Foreign Author, 50 COLUM. L. REV. 686 (1950).

${ }^{27}$ Rebecca Giblin, Reimagining Copyright's Duration, in WHAT IF WE COULD REIMAGINE COPYRIGHT? 194 (Rebecca Giblin \& Kimberlee Weatherall eds., 2017); Mark A. Lemley, IP in a World Without Scarcity, 90 N.Y.U. L. REV. 460 (on how people create without any economic incentive); James Boyle, The Second Enclosure Movement, 66 LAW \& Contemp. Probs. 33, 45-46 (2003). David A. Simon, Culture, Creativity, \& Copyright, 29 CARDOZO ARTS \& ENT. L.J. 279, 281 (2011); William Fisher, The Implications for Law of User Innovation, 94 MINN. L. REV. 1417, 1432 (2010); Roberta R. Kwall, Inspiration and Innovation: The Intrinsic Dimension of the Artistic Soul, 81 NoTRE DAME L. ReV. 1945, 1951-62 (2006); Lydia Pallas Loren, The Pope's Copyright? Aligning Incentives with Reality by Using Creative Motivation to Shape Copyright Protection, 69 LA. L. REV. 1, 8 (2008); David A. Simon, In Search of (Maintaining) the Truth: The Use of Copyright Law by Religious Organizations, 16 MICH. TELECOMM. \& TECH. L. REV. 355, 360-76 (2010); Roger Syn, Copyright God: Enforcement of Copyright in the Bible and Religious Works, 14 Regent U. L. REV. 1, 13-15, 27-28 (2002); Rebecca Tushnet, Economies of Desire: Fair Use and Marketplace Assumptions, 51 WM. \& MARY L. REV. 513, 526 (2009).
} 
proliferation of creative content on the web such as photos, videos, blogs, fanfiction, and publicly posted artwork. More creative content is now generated outside of traditional publishing streams and revenue streams than within them.

However, it is undeniable that some works would not come into existence but for the relationship between copyright protection and the path to traditional publishing. Some authors would not have the time, energy, or resources to create if they had to find other ways to financially support themselves and their dependents, and publishers would have little reason to invest in works that others could use freely. Even though these authors are in the minority of creators, outnumbered by those posting freely, society arguably would be weaker without them. After all, much of the nation's most-taught literature ${ }^{28}$ came about only after copyright protection was established. Some of the works themselves were directly shaped by compensation, such as novels that developed in part into substantial works because of the rewards that came from serial publication. ${ }^{29}$ Though copyright alone may not have caused these works to be created or published $^{30}$--- there were many other influences on the rise of writing and publishing in the guises of technology, lower cost publication materials, spread of literacy, increasing wages - it still served as a meaningful element in fostering an environment for greater production.

\section{How Technology Changed Copyright Practices}

[A]n author who publishes his or her writing and claims statutory copyright protection should not be free to play yo-yo with the public's right of access to a work of learning, because control of access is the essence of censorship. The right of public access, in short, is an implied condition for copyright protection just as originality is an express condition. ${ }^{31}$

The hallmark of the current intellectual property era is that technologies change rapidly, and legislatively-determined rights, like copyright, are slow to evolve. That puts the balance of copyright at risk, as technology has morphed so much more quickly than either Congress or the courts have been able to react. The inability for law to match real-time activities means that bad

\footnotetext{
${ }^{28}$ https://www.goodreads.com/list/show/478.Required_Reading_in_High_School

${ }^{29}$ Robert L. Patten, Pickwick Papers and the Development of Serial Fiction, 61 RICE UNIVERSITY STUDIES, Number 2 (1975) (describing how serial publications produced more financial rewards and incentives for publishers).

30 Though many of the titles still assigned in K-12 classes were indeed written only after copyright laws were enacted, there is reason to doubt that copyright was the only factor. Data from Our World in Data (https://ourworldindata.org/books) shows that various nations saw levels of publication pre-copyright that were not reached again until long after copyright laws were enacted. For example, the UK produced more new book titles in the mid-1600s than they did until the mid-1900s. The world is also well aware of respected artists and authors that created long-lasting works prior to any copyright laws. Shakespeare, da Vinci, and all of the artists from the Renaissance come to mind.

${ }^{31}$ Patterson, supra note 15 at 372-73.
} 
actors can act use new technologies to disrupt the balance of copyright long enough to do lasting damage before government acts. By the time legislation or a court opinion rules against the actor, the technology has already been replaced with something new, enabling the actor (or new actors) to expand on the damage in a different way or to choose an alternative angle of attack. In this way, bad actors manage to stay one step ahead of the law.

Such actors exist on both sides of copyright's balance, and this type of exploitative behavior has been undertaken in the past by members of the public as well as by copyright owners. Mass piracy, such as that undertaken by some of Napster's users, ${ }^{32}$ is an example of actions unbalancing copyright against its private purpose of compensating authors for their work. Technology, because of how quickly it can move files, enabled faster and more numerous transactions than was possible with analog works, making piracy easier and, in some cases, highly lucrative. ${ }^{33}$

On the flip side, technology has been used by copyright owners to retain all the advantages of copyright while evading the corresponding public responsibilities intended to come with those benefits. Copyright, which protects an intangible work, is by definition format neutral, as intangibility means that form is lacking. While format neutrality was respected in the analog world - a work was viewed as the same and worthy of the same protection whether in papyri, print, or microform ${ }^{34}$ - technology upended this core principle. ${ }^{35}$ Today, through intense lobbying of Congress by private rights owners, ${ }^{36}$ there are rights or remedies that attach solely to specific formats, even if the work in question and the intended use of it are the same as they would have been in print.

Dissatisfied with the legal mechanisms already in place to fight piracy (e.g., infringement remedies), private corporations pushed for extraordinary protection for works packaged in digital formats such as the anti-circumvention provisions of the Digital Millennium Copyright Act (see infra). ${ }^{37}$ This fear of piracy led to the adoption of strategies that assume that every member of the

\footnotetext{
32 Jennifer Norman, Staying Alive: Can the Recording Industry Survive Peer-to-Peer?, 26 COLUM. J.L. \& ARTS 371 (2003)

${ }^{33}$ SteVen WitT, How Music Got FreE (2015) (describing the earliest pirating efforts in music and movie DVDs and CDs).

${ }^{34}$ During the first couple of decades in the 1900s, there was some dispute about format and the application of copyright. The format in question was that of piano rolls, and the question was whether music in such a form infringed copyright if permission from the copyright owner had not been obtained. See White-Smith Music Pub. Co. v. Apollo Co., 209 U.S. 1 (1908) as an example. But that line of reasoning has not been repeated and later statutory enactments made clear that copyright protects a work, regardless of format.

${ }^{35}$ Congress' decision to upend neutrality was a conscious one. "In explaining this departure, the Commerce Committee notes that 'the digital environment poses a unique threat to the rights of copyright owners, and as such, necessitates protection against devices that undermine copyright interests." David Nimmer, Appreciating Legislative History the Sweet and Sour Spots of the DMCA's Commentary, 23 Cardozo L. Rev. 909, 920 (2002) citing the Report of the House Commerce Comm., H.R. Rep. No.105-551, Part 2, (2d Sess. 1998) at 25. ${ }^{36} \mathrm{Id}$.

${ }^{37}$ Over four days of testimony, copyright industries repeatedly cited unproven harm caused by piracy; piracy itself was clearly proven, but harm (e.g., that those consuming pirated works would have purchased them otherwise) was
} 
public is a pirate and cannot be controlled without industry action. This means that most solutions implemented are prior restraints on behavior, eliminating opportunities for public interests to act, leaving only private interests in control. Worse, those private interests shaping the nation's laws are not necessarily those protected by the Copyright Act; instead, it is often a publishers' private interest that shapes practice, and any practices adopted often survive even after having shown to fail in their purpose ${ }^{38}$. In other words, the sacrifice of the public interest remains even if the private interest is not well served.

While acknowledging that the balance of copyright can be upset in either direction, this article will discuss almost exclusively the problem of unbalancing of copyright in favor of private interests. This is for three reasons. The first is that the unbalancing of copyright in the other direction, against private interests, only exists where the authors' private interest in earning income for her work is compromised. The poster child for this type of imbalance is piracy, and that issue, mostly in music and movies, has been covered extensively. By the early 1990s, over 40 studies had been conducted, some showing a positive effect on sales and other negative effects. Scholars looking at the body of literature as a whole found that even where effects were identified, some were negligible, and "an effect cannot be proven beyond reasonable statistical doubt." 39

Piracy undoubtedly exists, but it is likely impossible to prove that it is the cause of any industry-wide decline in paid use. Even in eras where piracy is high and use low, industries would need to resolve two basic assumptions. The first is to account for the weight of other factors. Take broadcast television in illustration. Viewership might decline as piracy increases but other plausible factors include the proliferation of other entertainment sources both free (e.g., YouTube) and paid (e.g., Netflix), changes in viewer interests, and changes in demographics.

not. NII Copyright Protection Act of 1995 (Part 1) Before the H. Comm. on Judiciary, Subcom. on Courts and Intellectual Property (Nov. 15, 1995); NII Copyright Protection Act of 1995 (Part 2) Before H. Comm on Judiciary, Subcom. on Courts and Intellectual Property (Feb. 7-8, 1996; National Information Infrastructure Copyright Protection Act of 1995 Before S. Comm. on Judiciary (May 7, 1996).

${ }^{38}$ John T. Holland, Making Money Instead of Excuses: A Market-Based Alternative to the Digital Millennium Copyright Act That Protects Copyrights Without Diminishing Expression, 7 GEO. J.L. \& PUB. POL'Y 279, 292-4 (2009) (explaining why the anti-circumvention provisions in the DMCA were ineffective). See also, WILLIAM F. PATRY, HOW TO FIX COPYRIGHT 33, 72-73 (2011) (giving examples of where legislators are hoodwinked by disproven industry statistics or where post-legislation examination indicates that assumptions underlying the legislation were false. In the latter case, legislators still do not reverse course). See also IAN HARGREAVES, Enforcement and Disputes, in Digital OPPORTUNITY: A REVIEW OF INTELLECTUAL PROPERTY AND GROWTH (2011), https://assets.publishing.service. gov.uk/government/uploads/system/uploads/attachment_data/file/32563/ipreviewfinalreport.pdf; THE SOC. SCI. RESEARCH COUNCIL, MEDIA PIRACY IN EMERGING ECONOMIES (Joe Karaganis ed., 2011), https://www.ssrc.org/publications/view/C4A69 B1C-8051-E011-9A1B-001CC477EC84/

${ }^{39}$ João Pedro Quintais \& Joost Poort, The Decline of Online Piracy: How Markets - Not Enforcement - Drive Down Copyright Infringement, 34 AM. U. INT'L L. REv. 807, 815-16 (2019) citing Wojciech Hardy et al., Friends or Foes? A Meta-Analysis of the Link Between "Online Piracy" and Sales of Cultural Goods 2 (Univ. Warsaw Fac. Econ. Sci. Working Paper No. 23, 2015). 
Even if all other factors are eliminated or diminished, the industry would then need to verify that those consuming pirated goods would have purchased copies at the offered price. However, it is more likely that what they would find is that some may have insufficient financial means to purchase, others may live in regions where a legal version is unavailable, and still others may well lose interest if a product is available only at a cost. This last category may indeed be the most challenging to overcome, as everyone has probably experienced this phenomenon in their lifetime, picking up a free gift that they would not have purchased.

Correlation is simply not the same as causation, and for all the claims that piracy harms sales, analyses prove that if harm exists, it is not accurately represented by the data that industries present. ${ }^{40}$ Further, artists themselves have recognized instances where piracy has increased their sales. ${ }^{41}$ In short, without proof of causation of harm to the private interest, and therefore, accurate identification of a problem, a "solution" is premature.

The second reason to focus on bad industry actors is that the public purpose in copyright is the interest given the most weight in the Constitution so any diminution of its strength is of particular concern. In the case of harm to the public interest, the objective proof is set forth in the following subsections, making the issue ripe for discussion.

The last reason is that a small number of industry actors hold such power that they can unilaterally impact both the market and the public interest. In comparison, when members of the public act (e.g., use of Pirate Bay) to unbalance copyright, multiple actors have to be willing to act to do any damage (e.g., someone has to upload a work, and others who would otherwise buy the work would have to download it). When a powerful publisher acts, it can singlehandedly, unilaterally cut off any other routes and dictate all terms. It is possible to craft effective solutions to prevent harmful actions of a small number of multi-national corporations in a way that it is not practically possible to do for large populations where its members act independently.

\section{Licensing}

While some publishers still make titles available in multiple formats, offering any given book in print and online, others only offer licensed digital formats. By replacing sales with licensing, these publishers have eliminated copy ownership and all of the alienation rights attendant to it. To fully understand how disruptive and harmful this shift can be, one need only consider what types of public benefits alienation generate. It creates inventory for second-hand markets such as eBay, thrift shops, and used bookstores. It allows people to donate reading materials to libraries or charities so that those unable to afford the works can still access them. It enables friends to

\footnotetext{
${ }^{40}$ IAN HARGREAVES, supra note 38 at II 8.9 (finding no evidence supporting the claims of high losses because of digital piracy); SOC. SCI. RESEARCH COUNCIL, supra note 38 at 4 (noting "a serious and increasingly sophisticated industry research enterprise embedded in a lobbying effort with a historically very loose relationship to evidence").

${ }^{41}$ PATRY, supra note 38 at 157-158. See also commentary by Neil Gaiman on how his views on piracy changed, from fear of loss of income to recognizing that both piracy and free access had led to increased sales https://zine.openrightsgroup.org/features/2011/video:-an-interview-with-neil-gaiman
} 
lend their books to each other, for libraries to lend books to their communities, and for one generation to pass down their favorite titles to the next generation. Now imagine what happens if none of these actions are permitted.

Before examining licensing harms in greater detail, it is important to mark the scope of criticism. With all the harm that licensing can do when it replaces ownership, not all licenses have this purpose. In fact, licenses of copyrighted works themselves are not inherently harmful, as there are many that have beneficial and unique aspects beyond what is traditionally conveyed through copyright. Some aggregator databases or streaming services, for example, can give users and libraries options to access large quantities of information or services that would not be affordable through purchase. In many cases (particularly for the individual user), that type of expansive, temporary access may bring a greater benefit than purchasing a smaller, permanent collection. Short-term licenses for materials that libraries and individuals have no interest in owning (e.g., many multiple copies when a best-seller is released) also may be better met by short-term rentals than long-term purchases. Since the intent of access in these databases and their associated licenses is very different from a traditional acquisition, limiting rights in exchange seems to present a legitimate, conscious, mutually beneficial trade-off.

However, licensing practices for electronic materials that seek to replace a standard acquisition with a restrictive lease are harmful. They disable societal guarantees, such as preservation, meaning that content can disappear with no warning. They often charge higher prices for works while conveying fewer rights, infringe on privacy, and decimate industries and public services reliant on alienation principles.

It is this second category of licenses that will be the focus of this section.

\section{Licensing - Individuals}

Publishers licensing e-books to individuals often engage in objectively harmful practices including deception, loss of privacy, and loss of alienation. Amazon will be used for purposes of illustration in this subsection.

The deception comes in the characterization of a license as a sale, when a license by definition is only a lease where the original owner retains rights over use. For example, where Amazon offers books in multiple formats, each selection appears to allow the user to buy the book regardless of format. Any print edition (e.g., paperback or hardback) will offer a "Buy Now" button, and any digital edition (e.g., Kindle or Audible editions) will say "Buy Now with 1-Click". What does not appear throughout a digital purchase, though, is a notice that ownership is never transferred and the "buyer" has not actually purchased anything. They have licensed a book and own nothing. While the publisher/distributor is well aware of the differing consequences of each format's transaction, the wording misleads the user into thinking that the formats are simply alternative containers for the same content. They may not realize what rights they have lost if they choose a digital format. 
Those aware that the formats are subject to different terms can identify the unspoken costs of the digital format if they search for the license terms. A print book is owned and therefore, all the rights of ownership, including alienation, attach to it. The owner can lend the book to others, resell it, take it apart (e.g., incorporated into artwork), donate it, or pass it on to someone else upon death. In contrast, Amazon's terms for their Kindle format ${ }^{42}$ limits the buyer's use of an e-book only to types of devices and apps that Amazon recognizes (see italicized wording below), prohibits reconveyance (see bolded, underlined language below), and requires use to be personal and non-commercial (see underlined language below).

Use of Kindle Content. Upon your download of Kindle Content and payment of any applicable fees (including applicable taxes), the Content Provider grants you a non-exclusive right to view, use, and display such Kindle Content an unlimited number of times, solely through a Reading Application or as otherwise permitted as part of the Service, solely on the number of Supported Devices specified in the Kindle Store, and solely for your personal, noncommercial use. Kindle Content is licensed, not sold, to you by the Content Provider. The Content Provider may include additional terms for use within its Kindle Content. Those terms will also apply, but this Agreement will govern in the event of a conflict. Some Kindle Content, such as interactive or highly formatted content, may not be available to you on all Reading Applications.

Amazon's Kindle does allow for lending for some titles, but it not apparent from the initial transaction which titles are lendable and which are not. While a user can find the information if they know to look for it, it is buried. ${ }^{43}$ Also, since any information provided on lendability can change throughout the course of a license, that initial disclosure carries very little meaning beyond what the user can do at that exact moment if they choose to license the book. ${ }^{44}$ Even where a title is lendable, it may only be lendable once. While the decision on lending is not Amazon's responsibility, as that is set by the publisher of any given title, the opaqueness surrounding lendability is.

Further, the user gives up privacy rights without ever having consented to such loss of privacy.

\footnotetext{
${ }^{42}$ https://www.amazon.com/gp/help/customer/display.html?nodeId=200771440 (last visited April 30, 2021).

${ }^{43}$ One can find the information on lendability by following the steps described at https://bookriot.com/how-to-lenda-kindle-book/ (last visited July 1, 2021).

${ }^{44}$ See user thread on lendable books becoming unlendable at https://www.amazonforum.com/s/question/0D54P00006zIAl2SAG/why-are-so-many-books-no-longer-loanable (last visited July 1, 2021)
} 
Information Provided to Amazon. The Software will provide Amazon with information about use of your Reading Application and its interaction with Kindle Content and the Service (such as last page read, content archiving, available memory, up-time, log files, and signal strength).

Among the many datapoints Amazon gathers, it knows what any given user has read, how many times, what she has highlighted or bookmarked, the speed at which she reads, and the subjects that interest her. ${ }^{45}$ While some of this activity could produce effects favorable to the user, such as better recommendations on new materials or improvements to Kindle functionality, it is not necessary to track every Kindle action to reach these benefits. Other e-book vendors or platforms vary in the type of information they collect, but all collect information beyond what is necessary to give the user meaningful access to the book and associated functionalities. ${ }^{46}$

Last, Amazon can change the terms at any time, without notice. This includes unilaterally retracting the book, an option that it has exercised in the past. ${ }^{47}$

Changes to Service; Amendments. We may change, suspend, or discontinue the Service, in whole or in part, at any time without notice. We may amend any of this Agreement's terms at our sole discretion by posting the revised terms on the Amazon.com website. Your continued use of the Software or any aspect of the Service after the effective date of the revised Agreement terms constitutes your acceptance of the terms.

The consequences of these licensing practices for individuals, then, mean not only the eventual disintegration of second-hand markets and less sharing of information, but also the loss of individual control, choice, and privacy.

\section{Licensing - Libraries}

\footnotetext{
${ }^{45}$ Chaim Gartenberg, Why Amazon is tracking every time you tap your Kindle, VERGE (Jan. 31, 2020), https://www.theverge.com/2020/1/31/21117217/amazon-kindle-tracking-page-turn-taps-e-reader-privacy-policysecurity-whispersync. Note that it is possible to ask Amazon for a record of the data it has collected on you (https://www.amazon.com/gp/help/customer/display.html?nodeId=GXPU3YPMBZQRWZK2) but there does not appear to be a way to erase that data without deleting the entire account. Even then, unless the user lives in a country with strict privacy laws, Amazon has no obligation to erase information it has already collected.

${ }^{46}$ See Overdrive's privacy policy, http://company.cdn.overdrive.com/policies/privacy-policy.htm; Adobe Digital Edition's privacy policy, https://www.adobe.com/privacy/policies/ade.html. Additional privacy reviews of reading applications can be found at Common Sense at https://privacy.commonsense.org/

${ }^{47}$ Brad Stone, Amazon Erases Orwell Books from Kindle, N.Y TIMES, July 17, 2009, https://www.nytimes.com/2009/07/18/technology/companies/18amazon.html.
} 
Libraries are entities designed to serve the public interest of copyright, by preserving and providing access to information to current and future generations regardless of the requestor's wealth. For that reason, as troubling as the consequences of licensing are for individual purchasers, licensing practices applied to libraries can result in unique societal harm.

Not only do the general harms of licensing over ownership (e.g. elimination of alienation) apply to libraries, but publishers have layered on additional burdens when a library acquires content. Common publisher practices include refusing to sell materials to libraries, "taxing" library acquisitions, prohibiting activities that fall within a library's primary purpose (acquiring content, lending, preservation, ILL) and using changing technologies (i.e., digital format) to disable actions that were legal in an analog world.

In a digital world, publishers can control not only production but distribution, and through that power, some publishers have denied libraries access to content completely, something that was not possible in an analog world. In print, in the highly unlikely case of a bookstore declining to sell a title to a library, there would undoubtedly be alternative suppliers without such objections. With the digital format --- that same title simply wrapped in a digital container --- a publisher can outright refuse to sell or license the title to a library at all or require its distributors to do the same. Amazon, Simon \& Schuster, Macmillan, and some textbook publishers serve as examples, each of which has refused to license e-books to libraries at various points in time. ${ }^{48}$

Publishers have not been reticent about the rationale for their actions: private profit.

The growth in our digital business gives us access to a greater number of students in any given classroom and generates new sources of revenue from our existing adoption customers. In contrast to print publications, our digital products cannot be resold or transferred. We therefore realize revenue from every end user. ${ }^{49}$

Even when publishers are willing to license to libraries, the differential pricing is often crushing. Many publishers charge libraries several times more than individuals for e-book

\footnotetext{
${ }^{48}$ Geoffrey Fowler, Want to borrow that e-book from the library? Sorry, Amazon won't let you, WASHINGTON POST (Mar. 12, 2021), https://www.washingtonpost.com/technology/2021/03/10/amazon-library-ebook-monopoly/ Jordan Crook. See also AM. LIBRARY AsS’N, COMPETITION IN DIGITAL MARKETS 2 (2019), http://www.ala.org/news/sites/ala.org.news/files/content/mediapresscenter/CompetitionDigitalMarkets.pdf (describing Amazon's recent decision to stop selling e-books to libraries); Letter from SPARC to Assistant Attorney General Makan Delrahim, https://sparcopen.org/wp-content/uploads/2019/08/DOJ_Filing_08142019830.pdf (Aug. 14, 2019) (describing textbook publishers' refusals to license works to libraries); Carnegie Public Library, https://www.carnegie.lib.oh.us/content/did-you-know-your-library-cant-buy-ebooks-many-publishers (while now outdated, this site lists publishers that did, at the time of posting, refuse to license content to libraries).

${ }^{49}$ SPARC, supra note 48 at 11 (citing Cengage, Cengage Learning Holdings II, Inc.: Annual Report for Fiscal Year Ended March 31, 2019, at 6).
} 
licenses ${ }^{50}$ despite the fact that the content is exactly the same. Adding to the harm to the public interest, the licenses often come with restrictions whether in time or number of uses, meaning that a library would have to pay that artificially elevated price many times over for continued use of the same title. Funds that could have purchased 100 print books may only be able to license a dozen of those same titles in e-book format. Exactly the same content, but in one form (digital), less content for the community, no rights of preservation, and restricted rights of access.

These restrictions on library use are even more troubling because they run counter to the historical reality of public use. For instance, publishers such as HarperCollins unilaterally decided that e-books licensed to libraries would expire after 26 uses, ${ }^{51}$ despite the ease of verifying actual library usage where (1) the vast majority of books last significantly longer than that 26 uses through standard maintenance and repair and (2) libraries replace only a very small number of titles ${ }^{52}$. The publisher-set restriction is an artificial one, forcing purchase for continued use in one format when there would be no legitimate equivalent forced sale for its analog formats.

The same stark contrast is apparent in additional ways. Virtually all libraries have physical books in their stacks that are as old as their own existences, spanning decades if not centuries. They were obtained through gift or for a one-time fee and have been used continually since. The only "added" costs during the years of ownership are in repair and maintenance. In

\footnotetext{
50 "Abusive pricing for libraries also is typical from the Big 5 publishers. For example, The Codebreakers by David Kahn and published by Simon \& Schuster was quoted for \$59.99 as an eBook for a consumer purchase8-which means lifetime access. By contrast, the price to 3 libraries for the very same eBook is $\$ 239.99$ - and this is for one copy (i.e., it can be loaned out to one person at a time, simulating the print loan model) and lasts for only two years. If a library wanted access for four years, it would pay $\$ 479.98$. If the library wanted access for 20 years, it would pay a staggering $\$ 2,399.90$ - for one copy, lending that eBook to one person at a time." AM. LIBRARY ASS'N, supra note 48 at 2-3; Devin Coldewey, Necessary Evil? Random House Triples Prices of Library E-Books, TECHCRUNCH (Mar. 2, 2012), https://techcrunch.com/2012/03/02/necessary-evil-random-house-triples-prices-of-library-e-books/. This practice has long been in place, as differential pricing was already raised as a concern during the hearings over the 1909 Act. See To Amend and Consolidate the Acts Respecting Copyright: Hearing on S. 6330 and H.R. 19853 Before the S. Comm. On Patents and the H. Comm. on Patents, conjointly, 59th Cong. 75 (1906) (Testimony of William P. Cutter, Secretary, Library Copyright League; Copyright Law Revision, Part 1: Hearing on H.R. 2223 Before the H. Sub. Comm. On Courts, Civil Liberties, and the Administration of Justice of the Comm. on the Judiciary, 94th Congress 190 (1976) (Testimony of Edmon Low, representing six library associations). Please note that these are costs related to books that are used one person at a time; it does not analyze costs that may be added due to greater access such as unlimited simultaneous access, as the expanded scope makes this fundamentally different from borrowing a print equivalent, which by definition cannot be accessed by multiple people simultaneously.

51 Julie Bosman, Publisher Limits Shelf Life for Library E-Books, N.Y. TIMES, Mar. 14, 2011, https://www.nytimes.com/2011/03/15/business/media/15libraries.html.

${ }^{52}$ Library integrated library systems (ILSes) are typically set not to preserve identifiable circulation data permanently but they do generally record how many times an item has been checked out. As a former ILS administrator and law library director, I had access to such records, and every library where I have worked had works that circulated hundreds if not thousands of times without replacement (e.g., Bluebook).
} 
contrast, that same title in digital format may expire after a year or two, and a library has to repay for access to the same content.

Macmillan's decision, now reversed, to limit the copies of e-books a library could license, regardless of how large the community that library served, was based on the belief that readers would buy the books if the alternative was to stand in a virtual line in the form of a long library waiting list. ${ }^{53}$ While this assumption was perhaps true for some readers, what the publisher ignored in its calculation was that many other readers lacked the funds to purchase books at all.

Beyond overtly profit-motivated structures, many license terms also restrict what libraries can do with licensed content, undermining some of the rights explicitly granted to libraries in $\S 108$ (e.g., interlibrary loan, preservation copies) of the copyright code. Again, because use is governed by licenses and escapes the definition of ownership, $§ 108$ does not apply to licensed content. The harms caused by such terms echo throughout society. By limiting what can be loaned through interlibrary loan, all communities face an unnecessary loss of access to a broader range of materials than any given library can acquire. And, in preventing preservation, there is no reliable way to ensure that knowledge available today will still be verifiable tomorrow.

As noted earlier, loss of ownership for individuals has the downstream effect of crippling secondary markets and second-hand charitable uses. But loss of ownership to libraries means the eventual loss of information access to current and future generations. Prior to the digital age, libraries would purchase books. If a library's budget faced cuts in a given year, its community retained access to all of the content purchased in the decades or centuries before, even if it could not buy new content. With the shift to digital licenses instead of sales, a budget cut can mean that the library and its community loses access to all of that license's content, no matter what was spent in the years before. For society more broadly, materials available only through license may disappear entirely if a publisher goes out of business or otherwise decides that maintaining the records is no longer in its business interests. ${ }^{54}$

\section{Digital Millennium Copyright Act (DMCA)}

Until the adoption of the DMCA, Congress had generally remained faithful to both objectives of the Copyright Clause "by regulating the use of information--not the devices or means by which the information is delivered or used by information consumers--and by ensuring an appropriate balance between the interests of copyright owners and information users." 55 The anticircumvention and copyright management information provisions of the DMCA consciously

\footnotetext{
${ }^{53}$ Lynn Neary, You May Have To Wait To Borrow A New E-Book From The Library, NPR (Nov. 1, 2019), https://www.npr.org/2019/11/01/775150979/you-may-have-to-wait-to-borrow-a-new-e-book-from-the-library.

${ }^{54}$ While efforts like LOCKSS and CLOCKSS exist for preservation, these often require publisher or copyright owner approval for inclusion. While academic publishers have generally been willing partners, this cannot be said for the majority of all publishers.

${ }^{55}$ Report of the House Commerce Comm., H.R. Rep. No.105-551, Part 2 (2d Sess. 1998) at 24.
} 
departed from that balance, as Congress allowed industry fears of widespread piracy to overrule centuries-long principles. ${ }^{56}$

The mechanism through which the legislature decided to protect digital works was to provide them with additional protections, above and beyond copyright: they enacted civil and criminal penalties for circumventing technology, assisting others to circumvent technology, or damaging copyright management information.

The acts prohibited under the anti-circumvention provisions are described in $\S 1201$ :

(a) Violations regarding circumvention of technological measures.-(1)(A) No person shall circumvent a technological measure that effectively controls access to a work protected under this title....

(b) Additional violations.--(1) No person shall manufacture, import, offer to the public, provide, or otherwise traffic in any technology, product, service, device, component, or part thereof, that--

(A) is primarily designed or produced for the purpose of circumventing protection afforded by a technological measure that effectively protects a right of a copyright owner ...;

(B) has only limited commercially significant purpose or use other than to circumvent protection afforded by a technological measure that effectively protects a right of a copyright owner ...; or (C) is marketed by that person or another acting in concert with that person with that person's knowledge for use in circumventing protection afforded by a technological measure... ${ }^{57}$

And the prohibited acts related to copyright management information are found in $\S 1202$ :

(a) False copyright management information.--No person shall knowingly and with the intent to induce, enable, facilitate, or conceal infringement--

(1) provide copyright management information that is false, or

(2) distribute or import for distribution copyright management information that is false.

\footnotetext{
${ }^{56}$ Though the purported reason for the DMCA was the implementation of a WIPO treaty, legal scholars regularly noted that the anti-circumvention provisions went beyond what the treaty required. Laura J. Robinson, Anticircumvention Under the Digital Millennium Copyright Act, 85 J. PAT. \& TRADEMARK OFF. SOC'Y 957, 958-60 (2003)

${ }^{57} 17$ U.S.C. $§ 1201$.
} 
(b) Removal or alteration of copyright management information.--

No person shall, without the authority of the copyright owner or the law--

(1) intentionally remove or alter any copyright management information,

(2) distribute or import for distribution copyright management information knowing that the copyright management information has been removed or altered without authority of the copyright owner or the law, or

(3) distribute, import for distribution, or publicly perform works, copies of works, or phonorecords, knowing that copyright management information has been removed or altered without authority of the copyright owner or the law... ${ }^{58}$

The penalties for violation of either of sections are substantial and are independent of any damages awarded because of infringement. In other words, a user may be held liable under anticircumvention or copyright information management provisions even if they do not infringe on a copyrighted work. The civil penalties related to $\S 1201$ include actual damages or statutory damages up to " $\$ 2,500$ per act of circumvention, device, product, component, offer, or performance of service, as the court considers just" and up to $\$ 25,000$ per each violation of $\S$ $1202 .{ }^{59}$ The criminal penalties include fines up to $\$ 1,000,000$ or 10 years in prison. ${ }^{60}$

Despite the fact that copyright protects an intangible work, not a tangible copy of that work, in this single piece of legislation, Congress granted greater rights to producers of certain types of tangible copies over others as well as greater rights for many digital forms over analog ones. In application, the prohibition against circumvention acts as a prior restraint on fair use. Where a print copy of a work could be used freely under fair use principles, the digital equivalent of that same work could not, not because copyright prevents it but because the additional statute prohibiting circumvention criminalizes the act. ${ }^{61}$

The fear of piracy is inadequate to justify the sweeping nature of the DMCA. After all, the Copyright Act itself provides a remedy through damages for infringement, including

\footnotetext{
5817 U.S.C. $\$ 1202$.

5917 U.S.C. $\S 1203$. The amount of the award may be tripled if the act is repeated within 3 years of another violation of the act.

6017 U.S.C. $\$ 1204$. First offenses had a maximum $\$ 500,000$ fine or up to 5 years in prison, and repeat offenders faced the higher limits noted above.

${ }^{61}$ One scholar believes that the prior restraint can be challenged under current law. "The wording of the statute here opens the door for a court so inclined to evaluate the defendant's conduct and the effect of his using the subject work. If the factors for exemption are present, then that defendant, notwithstanding his failure to fall within the published regulations, may be able to prevail in arguing that he is exempt under the statute." David Nimmer, A Riff on Fair Use in the Digital Millennium Copyright Act, 148 U. PA. L. REV. 673, 698 (2000)
} 
enhanced damages for willful infringement. The anti-circumvention solution instead erected a barrier much wider than necessary to counter piracy, deterring as many, if not more, legitimate uses than it did infringing ones. Libraries that wanted to migrate a work from an obsolete format to a current one could not do so if the copy was protected by DRM. Purchasers of DVDs with specific regional coding were prohibited from removing the coding to view the content that they had purchased. Readers who wanted to view a purchased e-book on an application of their choosing instead of the one dictated by the publisher could not do so.

Admittedly, Congress did try to reconcile fair uses with these new provisions by including a few explicit exceptions (e.g., encryption research, interoperability) and by granting to the Librarian of Congress the authority to set additional exemptions every three years. ${ }^{62}$ But the latter mechanism does not prevent prior restraint. It simply creates a process to petition for an exemption, allowing the restraint to be removed after review; that removal must be reaffirmed each three years to remain in effect.

Note that criticizing the anti-circumvention provisions in the DMCA is not the same as opposing digital rights management (DRM) itself. DRM can be implemented in any number of ways - digital watermarking, encoding --- that do not upset the balance of copyright, so it is only the DMCA text and implementation that is under discussion here. Certain DRM mechanisms might be questionable, but most could be overcome if the DMCA did not grant extra protection to them.

\section{Industry Conglomerates' Interests Overtaking Author and Public Interests}

At the time of the nation's founding, the intended beneficiaries of the Copyright Clause - authors and users -- were roughly equal in stature, the first gaining benefits from what they created and the second in what it consumed. Neither had any power over the other except in a single financial transaction: the author's setting of a price for the initial sale, and the user's purchase of a copy at the stated price. The main shapers of copyright today, though, particularly in the industries reliant on individual use, fall into neither of those camps. They are instead the more powerful interests of employers and publishers. These often multi-national entities have leveraged the punitive aspects of copyright, the automation of technology, and their own power to tamp down copyright's private and public purposes.

\section{Diminishing Copyright's Private Interest (Author Revenue)}

Industry Conglomerates act against the private author interest in four ways: allowing works to go out of print while retaining control over publication (and therefore revenue streams), self-dealing such that payments to copyright owners are below market rate, deploying new technologies for greater exposure but lower royalty payouts, and closing off traditional revenue pathways.

${ }^{62} 17$ U.S.C. $\$ 1201$ (a)(1)(C). The current exemptions can be found at 37 CFR $\$ 201.40$. 
Both literary and musical works generally have short commercial life-spans, ${ }^{63}$ so it is not surprising that many go out of print when commercial interest is not considered adequate to justify further production. However, the continued control over the work (through contract) means that even if an author finds a new publisher or new market, she may have no ability to use that work to generate income ${ }^{64}$. Instead, the work sits unused, ${ }^{65}$ failing both purposes of copyright, neither generating income for the author nor contributing to the education or entertainment of the public.

The second category is self-dealing. The development of global, multi-media conglomerates, where a single entity has ownership interests in formerly vertical (e.g., publisher v. distributor) or horizontal (e.g., competing bookstores) business relationships, has made preferential treatment not only possible but likely. One such example is Fox's dispute with the artists and actors involved in the television show, Bones, where Fox had licensed the episodes to its subsidiaries and others using preferential license terms (e.g., freemium streaming, where users are not charged and rightsholders are not paid). According to an arbitrator, "Fox was self-dealing when it sold the show's digital rights to Hulu, potentially depriving the plaintiffs of millions in extra fees." ${ }^{66}$ Because Fox owned the rights to license and the artists contributing their work only were entitled to royalties, the conditions encouraged Fox to maximize its benefits from the use of the work without concern for the impact of reduced (or no) payments on its contributors.

Similarly, royalty calculations on streaming over purchase or single-work licensing have resulted in lower payouts to most creators as compared to music purchases, though payouts vary from platform to platform. One simplified comparison in 2013, for instance, determined that where an artist normally would have received $7-10 \%$ of the amount paid for a song download, they were receiving a fraction of a penny for each stream. ${ }^{67}$

Streaming itself is not the problem, as it presents additional options for author revenue and exposure, as well as an alternative means of consumption for the user. But the entities

\footnotetext{
${ }^{63}$ William M. Landes \& Richard A. Posner, Indefinitely Renewable Copyright, 70 U. CHI. L. REV. 471 (2003); EDWARD RAPPAPORT, supra note 5 at $5-15$.

${ }^{64}$ There is one narrow, statutory exception, that of the right of reversion contained in 17 USC \$304(c), which provides authors with a five-year window during which they can terminate a given grant.

${ }^{65}$ As an example, there was a time when approximately $95 \%$ of Motown Records' catalog was unavailable for purchase or licensing. PATRY, supra note 38 at 60.

${ }^{66}$ John Koblin \& Edmund Lee, Arbitrator Scolds Fox and Orders It to Pay \$178 Million to 'Bones' Team, N.Y. TIMES (Feb. 27, 2019), https://www.nytimes.com/2019/02/27/business/ media/bones-fox-arbitration-award.html

${ }^{67}$ Ben Sisario, As Music Streaming Grows, Royalties Slow to a Trickle, N.Y. Times (Jan. 28, 2013), https://www.nytimes.com/2013/01/29/business/media/streaming-shakes-up-music-industrys-model-for-royalties.html; Amy X. Wang, How Musicians Make Money--Or Don't at All--in 2018, Rolling STONE MaG. (Aug. 8, 2018), https://www.rollingstone.com/music/music-features/how-musicians-make-money-or-dont-at-all-in-2018-706745/ (estimating that artists receive less than 10\% of the revenues raised through streaming.); Dahrooge, supra note 6 at 212 (noting that the average Spotify payout is $\$ 0.00437$ per play).
} 
controlling payouts have actively sought to keep payouts artificially low. ${ }^{68}$ Initially, this position was "supported" by copyright law, as compulsory royalty rates for mechanical licensing 69 - what an entity had to pay for each physical copy (e.g. CD) it produced, which it was permitted to do with or without the copyright owner's approval once the work had been publicly distributed so long as the compulsory license fee had been paid - had not caught up to technology and did not apply to streaming. Later, publishers, artists, producers came to agreement on a standard compulsory rate to apply to streaming, ${ }^{70}$ but that agreement did not stop platforms from negotiating for even better rates, often keeping more of the income for itself than it would have through compulsory licensing. ${ }^{71}$ Subsequent lawsuits claimed copyright infringement and/or failure to pay out required royalties, ${ }^{72}$ with one report noting that Spotify failed to pay approximately $21 \%$ of royalties owed. ${ }^{73}$

Further, platforms have sued to prevent increases in royalty rates ${ }^{74}$ and have exploited loopholes in the Music Modernization Act, ${ }^{75}$ an act intended to establish fair statutory rates in the current digital environment. In one such action in 2020, Spotify, Amazon, Pandora, and Google won a lawsuit against the Copyright Royalty Board's 2018 decision to increase the overall percentage of revenue paid to songwriters from $10.5 \%$ to $15.1 \%$ over a five-year period. ${ }^{76}$ Spotify was the primary target of most protests, as their business model is built entirely on

\footnotetext{
${ }^{68}$ Chris Marple, The Times They Are A-Changin': How Music's Mechanical Licensing System May Have Finally Moved into the 21st Century, 26 RICH. J.L. \& TECH. 2 (2020).

6917 U.S.C. $\S 115$.

${ }^{70}$ Mechanical and Digital Phonorecord Delivery Rate Determination Proceeding, 73 FED. REG. 57,033 (Oct. 1, 2008) (codified at 37 C.F.R. §385).

71 “Spotify's new deals with major and independent labels, struck in the first half of 2017, in which the record companies agreed to lower the share of pro-rated net revenue they received from the platform, down from approximately $55 \%$ to $52 \%$." Since artists get paid a percentage of what their label gets paid, their income correspondingly decreases with each deal cut. Tim Ingham, Streaming Platforms are Keeping More Money From Artists than Ever (and Paying Them More, Too), Rolling Stone Mag. (April 9, 2019),

https://www.rollingstone.com/music/music-features/streaming-platforms-keeping-more-money-from-artists-thanever-817925/

${ }^{72}$ Ed Christman, Spotify Hit with $\$ 150$ Million Class Action Over Unpaid Royalties, BILLBOARD (Dec. 29, 2015), https://www.billboard.com/articles/business/6828092/spotify-class-action-royalties-david-lowery-cracker-150million [https://perma.cc/Z9TZ-EDP7];

${ }^{73}$ Ethan Smith, Songwriters Lose Out on Royalties, WALL ST. J. (Oct. 14, 2015), https://www.wsj.com/articles/songwriters-lose-out-on-royalties-1444864895

${ }^{74}$ Amy X. Wang, Apple and Spotify Are Dueling Over How Much to Pay Songwriters, Rolling StOnE MAG. (Mar. 16, 2019) https://www.rollingstone.com/pro/news/apple-spotify-pay-songwriters-808790/

75 Pub. L. 115-264 (2018).

76 Johnson v. Copyright Royalty Bd., D.C. Cir., No. 19-1028, decision unsealed Aug. 11, 2020. https://www.musicbusinessworldwide.com/sona-hits-back-at-spotify-crb-appeal/. See also Tim Ingham, Spotify vs. songwriters: Irving Azoff, Justin Tranter and other leading music biz figures slam streaming company's royalty rise appeal, MUSIC BUSINESS WORLD (Mar. 10, 2019), https://www.musicbusinessworldwide.com/spotify-vssongwriters-irving-azoff-justin-tranter-and-other-leading-music-biz-figures-slam-streaming-companys-royalty-riseappeal/.
} 
copyrighted music, and their reported income and profits so high ${ }^{77}$ that denying incremental increases in income to the creators that made that profit possible seemed particularly offensive.

Eight Mile Style v. Spotify ${ }^{78}$ serves as another illustration of how Industry Conglomerates have shaped copyright law to serve their own purposes. The alleged facts are these: Spotify (and its licensing agent, the Harry Fox Agency (HFA)) failed to apply in a timely manner for a compulsory license to use Eminem's works (copyright owned by Eight Mile), it used these works despite the lack of a license, it tried to cover up these actions to avoid penalties or the higher royalty rates possible because of the failure to obtain a timely license, and it has attempted to pay for only a fraction of the billions of times the works have been streamed. ${ }^{79}$

At least with respect to one song (Lose Yourself), Spotify had managed to avoid paying Eminem for the use of his works by classifying it under "copyright control," an internal mechanism its agent used whenever a copyright owner could not be identified. Aside from the difficulty in believing that an experienced music agency would be unable to identify the copyright owner of an award-winning, top-charting song, Eight Mile claims to have past correspondence with HFA on ownership and the appropriate revenue splits. In other words, HFA knew the copyright owner and still designated the work as one in the "copyright control" category, effectively authorizing use without proper payment of royalties.

Adding to the injury, Eight Mile noted that the terms of the MMA would ensure that Spotify and HFA would never have to pay the price for deliberate and prolonged infringement. For those works subject to the compulsory rates of the MMA, the Act replaced the usual remedies --- including actual damages, statutory damages and attorneys' fees --- with a mere claim for royalties if a digital music provider is able to demonstrate compliance with a certain subsection of the Act. ${ }^{80}$ Anyone who filed a lawsuit before December 31, 2017 could still avail themselves of the former remedies, but those afterwards could not. Eight Mile has questioned the constitutionality these provisions, noting that they retroactively deny remedies for a taking of a vested property right.

That single provision in the MMA is only the tip of the iceberg, though. The MMA itself was drafted primarily by Industry Conglomerates and resulted in a series of provisions that benefited themselves at the cost of creators. The unusual circumstances surrounding creation and the clauses themselves have been covered in-depth in other publications, but two examples of their impact are these: (1) allowing accrued royalties for "unknown" works to be distributed to entities other than the copyright owner after 3 years, and ${ }^{81}$ (2) reserving 10 of 14 voting seats on the MMA's collective licensing collective's board of directors for music publishers, with the

\footnotetext{
77 Stuart Dredge, Spotify ended Q1 2021 with 158m subscribers (and a profit), MUSICALLY (April 28, 2021), https://musically.com/2021/04/28/spotify-ended-q1-2021-with-158m-subscribers-and-a-profit/.

${ }^{78}$ Eight Mile Style v. Spotify, Case No. 3:19-cv-0736 (U.S. D.C., MD Tennessee).

${ }^{79}$ Id. See First Amended Complaint for Copyright Infringement.

${ }^{80}$ Supra note 75 at (a)(10)(A).

${ }^{81} I d$. at $(\mathrm{d})(3)(\mathrm{J})$ (Distribution of unclaimed royalties section of MMA).
} 
remaining four seats assigned to song writers. ${ }^{82}$ Commentators have noted that the ultimate outcome of the MMA was to make publishers the determiners or who gets paid and how they get paid.

The publishers have gone so far as to claim that if the writer of a song doesn't file a proper claim within 36 months of performance, $100 \%$ of the royalties from those streams will instead be paid to the top publishers (and some of their biggest writers) via the world's largest "black box" of royalties...[T] he complicated organizational structure it establishes pretty much ensures that a big pile of money will end up in the black box, destined for distribution to the major publishers based on their market share. It is highly unlikely that the tens of thousands of independent self-published and unpublished writers whose music is performed on Spotify and other digital music services will ever get their fair share. ${ }^{83}$

Last, as noted in the section on Licensing, some publishers will not make their content available to libraries, which harms the public in the form of access but also harms the author in that there is less opportunity for the public to be exposed to their work. ${ }^{84}$

\section{Frustrating Copyright's Public Purposes}

The harms to the public come in the chilling of innovation and the denial of fair uses. With every new technology - photocopier, Betamax, web, search engines ${ }^{85}$ - Industry Conglomerates have aggressively threatened litigation even when the uses in question were innovative, harm was speculative, and the public good was evident. But litigation is not the only tool used, so this

\footnotetext{
${ }^{82} I d$. at (d)(3)(D) (Governance section of MMA).

${ }^{83}$ Phil Galdston \& David Wolfert, supra note 6.

${ }^{84}$ Rachel Kramer Bussel, How Libraries Help Authors Boost Book Sales, ForBeS (April 12, 2019), https://www.forbes.com/sites/rachelkramerbussel/2019/04/12/how-libraries-boost-book-sales/. See also World Literacy Foundation, Power of Libraries, https://worldliteracyfoundation.org/the-power-of-libraries/ (showing how people who otherwise could not access resources gets exposure through libraries); Lisa Krolak, The Role of Libraries in Creating a Literate Environment, UNESCO (2005), (https://www.ifla.org/files/assets/literacy-andreading/publications/role-of-libraries-in-creation-of-literate-environments.pdf) (how access to libraries correlates to literacy; John B. Horrigan, Library Usage and Engagement, PEW RES. CTR. (Sept. 9, 2016), https://www.pewresearch.org/internet/2016/09/09/library-usage-and-engagement/ (providing demographics on library book use).

${ }^{85}$ Williams \& Wilkins Co. v. United States, 487 F.2d 1345 (1973), aff'd, 420 U.S. 376 (1975) (photocopying); Sony Corp. of Am. v. Universal City Studios, Inc., 464 U.S. 417 (1984) (Betamax home recording device); Perfect 10, Inc. v. Amazon.com, Inc., 508 F.3d 1146 (9th Cir. 2007) (web index of thumbnail pictures); Authors Guild v. Google, Inc., 804 F.3d 202 (2d Cir. 2015) (full-text searching of digitized books).
} 
subsection will examine not just formal legal action but also two other practices against the public interest: (1) suppressing automation even where it simply facilitates a user's use of purchased/licensed content and (2) using overbroad automated takedowns. Then, it will consider how copyright's statutory damages magnify chilling effects.

\section{Preventing Reasonable Uses of Licensed/Purchased Materials}

Industry Conglomerates have interceded quickly whenever automation potentially threatens their income streams, even where the automation is intended to facilitate use by a person who has already purchased or licensed a work. An example can be found in the attacks on automated technologies useful for those with disabilities or different learning styles. Amazon has faced such challenges at least twice. One of those actions may fall within the exemplars of a derivative work, ${ }^{86}$ which complicates the analysis, but the instances in question differ from how the exemplars were originally considered in the code, as they were not offered independently for sale, only available with licensed content. In other words, the copyright owners would have already been paid for the use of the work.

The first instance was in 2009, when the Kindle 2 introduced text-to-speech software that could read licensed e-books to its authorized users. The Authors Guild objected, claiming copyright infringement, and Amazon chose to deactivate the feature, instead giving each copyright owner the option to enable the feature for their e-book. ${ }^{87}$ This was the case even though the argument for infringement was poor. It was not a public performance of the work and the audio feature could only be used on demand by individuals who had already acquired the content. Even an argument that the audio was a derivative work would have been defeated, as a derivative requires fixation to meet the definition and an on-demand reading that is not preserved anywhere likely would escape its boundaries.

Later, in 2019, several publishers sued Amazon for infringement based on Audible's features, which essentially were the reverse of the ones in the earlier case-Audible provides speech-to-text. The publishers' claim was that Audible's ability to display the text of a book as it is being read (Audible Captions) creates a derivative work that competes with the market for Immersion Reading, another product offered by Amazon requiring the user to buy both the audio and text versions of a work. ${ }^{88}$ Though it had initially offered a fair use defense, Amazon/Audible ultimately chose not to litigate to a conclusion but instead reached an agreement that it would not enable this feature without publisher consent. ${ }^{89}$

\footnotetext{
8617 USC $\$ 101$.

87 Mike Masnick, Amazon Gives In to Ridiculous Authors Guild Claim: Allows Authors to Block Text-To-Speech, TECHDIRT (Feb. 27, 2009), https://www.techdirt.com/ articles/20090227/1759173928.shtml.

${ }^{88}$ Peter S. Lubin \& Patrick Austermuehle, Amazon's Audible Sued for Copyright Infringement over Caption Feature, CHI. Bus. LiTIG. LAw. BlOG (Oct. 10, 2019), https:// www.chicagobusinesslitigationlawyerblog.com/9096-2/.

${ }^{89}$ Chronicle Books, LLC v. Audible, Inc., No. 19-CV-07913 (S.D.N.Y. Aug. 23, 2019).
} 
The result in both cases harmed users over all others. Text-to-speech capability better serves the print disabled or even the physically disabled who may find it difficult to turn pages (physical or digital). Speech-to-text helps those with learning disabilities, those that may not learn well through speech but need to see words written out before them. ${ }^{90}$ Suppressing functions that would have made it easier for these individuals to use a work that they had purchased ${ }^{91}$ (1) undermines the Copyright Clause's intent to use inventions and writings to advance the progress of the sciences and the useful arts and (2) creates an unnecessary and illogical barrier to those seeking to use copies of the works that they have legitimately acquired.

Amazon, at least during the most recent lawsuit, was both powerful and wealthy but still capitulated. The costs of litigation ${ }^{92}$ and the potential of statutory damages ${ }^{93}$ make it even less likely that entities with fewer resources will choose to resist similar assaults.

\section{Libraries and Litigation}

Libraries saw this same aggressive stance from Industry Conglomerates with technology's use with books in the Google Books, HathiTrust, and Georgia State cases. ${ }^{94}$ Despite the public benefit, no demonstrated harm, and later evidence that the free or fair uses improves sales, ${ }^{95}$ publishers have continued to intimidate libraries engaging in arguably fair uses. The most recent example is Hachette Book Group, Inc. et al v. Internet Archive, ${ }^{96}$ a lawsuit that in part challenges the practice of Controlled Digital Lending (CDL). CDL is, at its heart, simply a shift in format. It posits that if a library acquires a book in print, it can convert it to digital form and circulate the

\footnotetext{
${ }^{90}$ Masnick, supra note 87; Peter S. Lubin \& Patrick Austermuehle, supra note 88.

${ }^{91}$ Jonathan Lazar, The Use of Screen Reader Accommodations by Blind Students in Standardized Testing: A Legal and Socio-Technical Framework, 48 J.L. \& EDUC. 185, 191-92 (2019) (explaining how screen readers work Lazar states, "[f]or a blind student who has no residual vision which would allow for the use of magnification, the screen reader output is to substitute for the text which appears on the screen. For a student with a learning disability, most often, the screen reader supplements the text on the screen, providing multi-modal visual and auditory feedback, where the word on the screen is highlighted as it is read by the screen reader. Screen readers are one of the most popular forms of assistive technology.").

92 The median costs for copyright litigation, inclusive of pre- and post-trial appeal where applicable, in 2019 were: $\$ 500,000$ (when $1 \mathrm{M}$ or less was at risk), \$1,750,000 (when between 1-10M was at risk), and \$3,500,000 (when between 10-25M was at risk), and \$6,500,000 (when over 25M was at risk). Even the costs just at early stages (initial case management) for low cost (1M or less at risk) had a median cost of $\$ 25,000$. AM. INTELLECTUAL PROP. LAW ASSOC., 2019 REPORT OF THE ECONOMIC SURVEY (2019).

${ }^{93}$ Ben Depoorter, Copyright Enforcement in the Digital Age: When the Remedy Is the Wrong, 66 UCLA L. REV. 400, 441 (2019)

${ }^{94}$ Authors Guild, Inc. v. HathiTrust, 755 F.3d 87 (2d Cir. 2014) (digitized books in the form of a searchable database, indexing and provision of full-text to print disabled); Authors Guild v. Google, Inc., 804 F.3d 202 (2d Cir. 2015) (digitized books in the form of a searchable database and further reproduction in the form of snippets); Cambridge Univ. Pr. v. Patton, 769 F.3d 1232 (2014) (e-course reserves).

95 Abhishek Nagaraj \& Imke Reimers, Digitization and the Demand for Physical Works: Evidence from the Google Books Project, https://papers.ssrn.com/sol3/papers.cfm?abstract_id=3339524

${ }^{96}$ Hachette Book Group, Inc. et al v. Internet Archive, Docket No. 1:20-cv-04160 (S.D.N.Y. Jun 01, 2020)
} 
digital version in place of the print. It can never simultaneously lend any more copies that it owned originally, and any digital copy has to be locked down so that it cannot be wholesale copied or redistributed. ${ }^{97}$ The parameters for format shifting as outlined in CDL retain the balance between the author's interest and the public interest intended by copyright laws; the author is paid at the time of the initial library acquisition, and the library uses only the number of copies acquired to provide public access to the work.

Even libraries with good faith beliefs that their use is fair may be hesitant to undertake a protracted and expensive battle ${ }^{98}$ because doing so means (1) committing to costly actions that have an uncertain outcome (fair use outcomes are not predictable), and (2) diverting resources from their intended use --- obtaining content for their communities - to legal defense.

\section{Automated Takedowns}

Any number of creators have used copyrighted works in fair uses, such as in criticism or parody of a given work, and sites like YouTube, Vimeo, and TikTok are replete with examples of both fair and infringing uses. Industry Conglomerates, in an attempt to catching infringement, have created and implemented automated tools to catch and suppress not only of infringing uses but also fair uses.

Computer algorithm systems that search the Internet for copyright infringements enable copyright holders who hold thousands of copyrights to identify and rapidly remove infringing material. Some businesses choose to hire outside firms to do their policing, yet some websites that host third-party material employ an inhouse automated process. Generally, the automated process includes searching keywords related to the copyrighted content. If alleged infringing material is identified, the system automatically sends a takedown notice to the host of the material, generally a website, in order to remove it from the Internet. If the host of the material is, for example, YouTube, a copyright holder can have the video removed in minutes if YouTube's own automated system detects it as possibly infringing. Thus, the entire process from

\footnotetext{
97 Position Statement on Controlled Digital Lending, CONTROLLED DigITAL LENDING BY LIBRARIES, https://controlleddigitallending.org/statement; Dave R. Hansen \& Kyle K. Courtney, A White Paper on Controlled Digital Lending of Library Books, CONTROLLED DIGITAL LENDING BY LIBRARIES (2018), https://controlled digitallending.org/whitepaper; Michelle M. Wu, Revisiting Controlled Digital Lending Post ReDigi, 24 FIRST MONDAY (2019), https://firstmonday.org/ojs/index.php/fm/article/ view/9644/7793; Michelle M. Wu, Piece-by-Piece Review of Digitize-and-Lend Through the Lens of Copyright and Fair Use, 36 LEGAL REF. SERVS. Q. 51 (2017).

${ }^{98}$ See supra note 92.
} 
which a lawful video may be removed from the Internet can escape human review. ${ }^{99}$

One particular practice that has come under fierce fire is the type of automation used by hosting platforms like YouTube. Their version is called Content ID and has resulted in any number of disputes over the validity of takedowns.

Since its launch, Content ID has received significant negative attention because it has incorrectly matched thousands of lawful videos as infringing on a copyright. Many uses of copyrighted material are in fact completely legal, yet Content ID is unable to distinguish lawful use from unlawful use. Accordingly, lawful videos are removed or blocked without any human oversight if a copyright holder has contracted with YouTube to block or remove a video when a match is made. Given the fact that the process of disputing a Content ID match favors the copyright holder rather than the content creator, speech may go censored for weeks, even years. $^{100}$

\section{Statutory Damages}

Each of the three subsections above highlight a subversion of copyright, and that effect is amplified when examining the consequences of threatened litigation and statutory damages. Inequality in litigation, where the party with greater power or wealth can prevail even when their substantive argument is weaker, is not unusual. ${ }^{101}$ Parties can and do overwhelm their opponents with filings, documents in discovery, or frivolous charges. Resource-rich entities will always be able to afford more personnel to research, pursue, and/or harass real or perceived infringers to the point where it is simply easier for the other side to cease action. ${ }^{102}$

Unlike naturally occurring divides, though, copyright's statutory damages is a legislatively-created power imbalance, weighing heavily in favor of the copyright owner. Legislative history shows that Congress had intended statutory damages to be largely compensatory and simply offered them as an alternative accounting measure when it would be

\footnotetext{
${ }^{99}$ Laura Zapata-Kim, Should Youtube's Content Id Be Liable for Misrepresentation Under the Digital Millennium Copyright Act?, 57 B.C. L. REV. 1847, 1856-57 (2016).

${ }^{100}$ Id. at $1863-64$.

${ }^{101}$ Marc Galanter, Why the "Haves" Come Out Ahead: Speculations on the Limits of Legal Change, 9 LAW \& SoC'Y REV. 95, 103-04 (1974); Albert Yoon, The Importance of Litigant Wealth, 59 DePaul L. Rev.649 (2010).

102 See Steven Shavell, Suit, Settlement, and Trial: A Theoretical Analysis Under Alternative Methods for the Allocation of Legal Costs, 11 J. LEGAL STUD. 55, 56 (1982).
} 
difficult to calculate actual damages. ${ }^{103}$ Congress explicitly noted that these types of awards "shall not be regarded as a penalty." 104 Had litigants and courts resorted to statutory damages in only in instances where harm could not be quantified, there would be little concern. But, litigants have asserted claims in the millions even when harm is at best speculative and at worst known not to exist. ${ }^{105}$

One need only look at past music file sharing cases against individuals to see how aggressively statutory damages can be used to intimidate and terrorize. One case found a single user, Jammie Thomas-Rasset, liable for $\$ 1.92$ million for downloading 24 songs, and another claimed that a senior citizen who only used a computer incompatible with the relevant peer-topeer file sharing software had used the software to infringe on copyrights. ${ }^{106}$ The examples here are not offered as actual consequences, as in many cases, the damages were appealed and/or remitted or the cases withdrawn or dismissed. They are proferred instead to demonstrate the chilling effect of aggressive litigants who demonstrate more interest in deterring future conduct than in justice. ${ }^{107}$ Had equity been the focus, the damages requested would have at most been the cost of the number of works downloaded.

Why is this important? Because fair use by definition requires a case-by-case analysis. Its body of law cannot evolve or adapt without individuals or organizations willing to explore its limits. When litigation is so costly that an innovator has to choose between testing a new fair use and bankruptcy, or a public provide choose between providing a public good and bankruptcy, those willing to take the risk fall drastically. That threat is heightened where the innovator is a non-profit entity and cannot count on income-generating activities as potentially offsetting any costs of innovation. ${ }^{108}$ The stakes created by statutory damages often means that only the wealthier, more powerful, or for-profit enterprises will be willing to test the limit or to defend their uses in court. Weaker or poorer entities innovate but back down in the face of litigation

\footnotetext{
${ }^{103}$ Pamela Samuelson \& Tara Wheatland, Statutory Damages in Copyright Law: A Remedy in Need of Reform, 51 WM. \& MARY L. REV. 439, 446 (2009).

${ }^{104}$ Copyright Act of 1909, Pub. L. No. 60-349, § 25(b), 35 Stat. 1075, 1081.

105 Capitol Records v. Thomas-Rasset, 579 F. Supp. 2d 1210, 1213, 1227 (D. Minn. 2008) (“Thomas allegedly infringed on the copyrights of 24 songs-the equivalent of approximately three CDs, costing less than $\$ 54$.”). The trial judge vacated an earlier judgment of $\$ 220,000$, partly from the believe Congress had not intended this sort of result. Id. at 1227 .

106 Genan Zilkha, The RIAA's Troubling Solution to File-Sharing, 20 FordHAM InTELL. PROP. MEDIA \& ENT. L.J. 667,668 (2010)

${ }^{107}$ Matthew Sag, Piracy: Twelve Year-Olds, Grandmothers, and Other Good Targets for the Recording Industry, 4 NW. J. TECH. \& INTELL. PROP. 133 (2006)

${ }^{108}$ Libraries have already seen this effect in the implementation of Controlled Digital Lending (CDL) where even libraries convinced of the fairness of the use were reluctant to engage in the practice because of the threat of litigation, not the threat of loss on the merits. This was the case despite the special protections afforded to libraries in $\$ 504$, reducing the threat of statutory damages.
} 
even where they think that they are substantively right, ${ }^{109}$ and this harms innovation and the advancement of society overall.

\section{Re-righting Copyright}

Anything short of complete copyright reform is unlikely to address the many imbalances in copyright identified by scholars over the years, ${ }^{110}$ but there are smaller steps that could make a significant difference in the specific instances described above. The subsections that follow explore actions already in progress as well as new proposals for change.

\section{Replace Statutory Damages}

Statutory damages have moved far from their intent, becoming a hindrance instead of a help to copyright itself. By revising statutory damages as many have suggested, ${ }^{111}$ a legislativelyprovided power imbalance can be eliminated and the overall power disadvantage in copyright litigation can be narrowed.

Since the purpose of statutory damages --- to provide some compensation to a copyright owner when actual damages cannot be proven --- is not what motivates the use of statutory damages today, ${ }^{112}$ the provisions are ineffective for their articulated purpose. The simplest solution is to eliminate statutory damages from the statute without any other alterations, and arguably, this step would still be consistent with Congress' initial intent. Since Congress had stated that statutory damages were not intended to be punitive but litigants have used them predominantly in that manner, elimination would simply be an acknowledgement that the provision failed in application and therefore was unneeded.

Realistically, though, litigation and subsequent legislation have shown that there is appetite and interest for some heighted measure of recovery when willful conduct is detected and

\footnotetext{
${ }^{109}$ While not directly involving the publishers at issue in this article, the effectiveness of the threat of suit is well known. Amanda Reid, Copyright Policy as Catalyst and Barrier to Innovation and Free Expression, 68 CATHOLIC UNIV. L. REV. 33, 58-67 (2019).

${ }^{110}$ Pamela Samuelson, Members of the CPP, The Copyright Principles Project: Directions for Reform, 25 BERKELEY TECH. L.J. 1175 (2010). WiLliam F. PATRY, HOW TO FIX COPYRIGHT 38 (2011). Christina Mulligan, Copyright Without Copying, 27 CORNELl J.L. \& PUB. POL'y 469 (2017). WHAT IF We CoUld REIMAGINE COPYRIGHT? 177 (Rebecca Giblin \& Kimberlee Weatherall eds., 2017). MiCHELLE M. WU, REBALANCING COPYRIGHT: CONSIDERING TECHNOLOGY'S IMPACT ON LIBRARIES AND THE PUBLIC INTEREST (Hein, 2021).

111 Just a few such examples: Depoorter, supra note 93 at 438-445; Samuelson, supra note 103; Joe Donnini, Downloading, Distributing, and Damages in the Digital Domain: The Need for Copyright Remedy Reform, 29 SANTA Clara COMPUTER \& High TeCH. L.J. 413, 444-449 (2013); Matthew Sag, Copyright Trolling, an Empirical Study, 100 IOWA L. REV. 1105, 1133-1144 (2015)

112 J. Cam Barker, Grossly Excessive Penalties in the Battle Against Illegal File-Sharing: The Troubling Effects of Aggregating Minimum Statutory Damages for Copyright Infringement, 83 TEX. L. REV. 525 (2004) (using statutory damages as a punitive measure); Depoorter, supra note 93 at 413-17.
} 
damages cannot easily be measured. To properly reflect that interest, standards should allow for punitive damages on top of actual damages. Any language should be calibrated properly to reflect this specific interest as well as to protect fair use and innovation. It should act to deter infringement that cannot be justified under one of the exceptions, particularly actions that make commercial use of a copyright owner's work without remuneration. But it also should not be interpretable as punishment for innovators who may be working in gray areas especially where they are engaging with new technologies.

Punitive damages are by definition not compensatory but instead designed to send a societal message that a defendant's recklessness, malice, or deceit will result in punishment beyond any measurable damage. Common law and federal statutes awarding punitive damages generally recognize that they can be awarded where "the defendant's conduct involves reckless or callous indifference to the plaintiff's federally protected rights, as well as when it is motivated by evil motive or intent."113

State tort law provides alternative reasons for punitive damages:

Punitive damages may be awarded for the purpose of punishment and for other purposes such as (1) to deter a particular tortfeasor; (2) to deter others from engaging in similar acts; (3) to provide additional compensation to sufferers from a defendant's reckless and wanton conduct; (4) to encourage persons who have suffered only nominal damages to sue those who conduct themselves outrageously; (5) and to provide a substitute for personal revenge by the wronged $\operatorname{party}^{114}$

Any of these standards would serve as suitable templates for punitive damages in copyright infringement cases.

To prevent punitive damages from being used to deter innovation and public uses as statutory damages have, though, the limits of applicability must be as clear as its requirements. In addition to the requirements such as recklessness, malice or deception, the infringer has to have harmed the market or the potential market for the work beyond just himself. Someone who downloads a song for his own use, then, could be sued for actual damages (i.e., the market cost of a copy of that song) but could not have punitive damages levied against him. The one exception here may be for repeat offenders who have already been found liable but continue to engage in the same behavior.

The harm to the market or potential market also has to be substantial. Under this limitation, someone who makes a single copy of a work and gives it to a friend could still only be held liable for the cost of one copy, whereas someone who uploads a copy to a pirate site for the

\footnotetext{
113 Smith v. Wade, 461 U.S. 30 (1983).

${ }^{114}$ Perry v. Melton, 171 W. Va. 397, 299 S.E.2d 8 (1982).
} 
world to download could be penalized with an award exceeding the cost of any copies downloaded.

To provide extra protection to innovators and public uses, Congress should retain the purpose of the second half of $§ 504(c)(2)$ which currently reads:

The court shall remit statutory damages in any case where an infringer believed and had reasonable grounds for believing that his or her use of the copyrighted work was a fair use under section 107, if the infringer was: (i) an employee or agent of a nonprofit educational institution, library, or archives acting within the scope of his or her employment who, or such institution, library, or archives itself, which infringed by reproducing the work in copies or phonorecords; or (ii) a public broadcasting entity which or a person who, as a regular part of the nonprofit activities of a public broadcasting entity (as defined in section 118(f)) infringed by performing a published nondramatic literary work or by reproducing a transmission program embodying a performance of such a work.

Altering it to read:

The court may not award punitive damages in any case where an infringer believed and had reasonable grounds for believing that his or her use of the copyrighted work was a fair use under section 107.

This provision remains necessary because some fair uses could be undertaken willfully or recklessly, elements that are usually used to determine culpability in punitive damages. After all, since fair use is most commonly a defense, the defendant will almost always have knowingly and deliberately engaged in infringement. By explicitly stating that those with a reasonable belief in a fair use cannot be charged with punitive damages, Congress would send a clear signal that they wish to protect the public interest. The expansion of the exemption to any actor instead of just the three currently specified sends the same message, that fair uses are protected and anyone with a reasonable claim of fair use should not be deterred from acting.

\section{Reaffirm Format Neutrality}

First sale, fair use, library uses... all of these public benefits have been eroded by Congress' judgement that digital formats deserve greater protection than physical formats. This extra protection is all the more puzzling because as technology advances, society has gained everyday tools to turn physical formats into digital ones (e.g., scanner apps) so that even two digital copies of a given work might be treated differently at law. 
Take, for example, an e-book from a publisher as compared to digital copy of that same title scanned in by a user of a print copy. The format for each is digital, but the first will be protected by publisher-DRM and therefore fall within the anticircumvention provisions of the DMCA. Except in cases where explicit exceptions have been made, the user of that publisherprovided e-book will be unable to use the content of that book for fair uses. The user who made their own digital copy, though, could use the digital copy for fair uses, providing that the digitization of the print title was also a fair use. While there are instances where the initial digitization would not be fair, at least in dicta, courts have indicated that reproduction could indeed be a fair use where the legitimate owner of the title is making the reproduction for his own personal use. ${ }^{115}$

If Congress restores format neutrality, copyright law and its associated rights will again be tied to the work only. All formats would be treated the same, and different copies in the same format will also be treated the same.

The first step toward reestablishing format neutrality would be to rewrite the anticircumvention provisions of the DMCA, as other scholars have suggested. ${ }^{116}$ While difficult politically to do, the change itself is a fairly straightforward one. Congress cannot eliminate circumvention laws entirely because of compliance issues with the WIPO Copyright Treaty, but the relevant WIPO provision reads only

Contracting Parties shall provide adequate legal protection and effective legal remedies against the circumvention of effective technological measures that are used by authors in connection with the exercise of their rights under this Treaty or the Berne Convention and that restrict acts, in respect of their works, which are not authorized by the authors concerned or permitted by law ${ }^{117}$ (emphasis added)

Lifting any prior restraints on circumvention, therefore, should keep the United States in compliance with the treaty while also permitting fair use and innovation. Since fair use is permitted by law, Congress could amend the statute applying fair use to circumvention as well as infringement. In other words, someone circumventing technology for a fair use of a work would be able to do so legally. No penalties would attach for circumvention unless the defendant engaged in copyright infringement without a legal justification for it.

\footnotetext{
115 Capitol Records, LLC v. ReDigi Inc., 910 F.3d 649, fn 16 (2018).

116 Selected examples of past commentary: Art Neill, Fixing Section 1201: Legislative and Regulatory Reforms for the DMCA's Anti-Circumvention Provisions, 19 Tul. J. TECH. \& InTELL. Prop. 27, 38-43 (2016); Joel D. Matteson, Unfair Misuse: How Section 512 of the DMCA Allows Abuse of the Copyright Fair Use Doctrine and How to Fix It, 35 Santa Clara High TeCh. L.J. 1, 15-18 (2018); Christopher Moseng, The Failures and Possible Redemption of the DMCA Anticircumvention Rulemaking Provision, 12 J. TECH. L. \& POL'Y 333, 335 (2007).

117 Article 11, WIPO Copyright Treaty, https://www.wipo.int/edocs/lexdocs/treaties/en/wct/trt_wct_001en.pdf.
} 
Most, if not all, critical analyses of the DMCA have come up with the same goal but have articulated different paths. ${ }^{118}$ The reason this article embeds the solution within the general principle of format neutrality is because the flaw in the DMCA lies in treating the electronic format as different from other formats; that same flaw exists in other aspects of copyright and all should be addressed at the same time (see the second step below).

While copyright owners, the PTO, and the Copyright Office might all object to this approach to the DMCA, emphasizing again the oft-repeated danger inherent in the rapidity with which digital works can be transmitted, the example at the start of this section should illustrate why the DMCA fails to address the concern. Other scholars have offered other reasons why the DMCA has failed at its purpose:

The efficacy of the DMCA rests upon the assumption that technological protections are a good way of securing copyrighted works. However, this assumption is questionable for three reasons: 1) determined hackers will inevitably defeat DRMs, thereby granting all users access to the underlying content; 2) holding individual users liable under the DMCA is unlikely to change user behavior in the aggregate; and 3) the DMCA cannot physically or electronically prevent users from circumventing DRMs or trafficking in circumvention technologies. ${ }^{119}$

Further, its failure is accompanied with its suppression of public uses, which means that it has failed not one, but both purposes of copyright.

The second step to format neutrality would involve explicitly applying existing exceptions, such as first sale, to all formats. Lawmakers' and administrations' unfamiliarity with technology may have justified the conservative approach taken in earlier years, but that understanding should now be informed by actual use. Piracy existed before copyright, survived through every legislative enactment thereafter, and will continue despite future lawmaking attempts. The reasons for this vary from practicality (e.g., inability to afford a legal copy), to ignorance of the laws (e.g., how many users are actually aware of the DMCA's penalties?), to indifference to the laws (e.g., much like that felt for traffic laws), to outright scorn for any regulation. ${ }^{120}$ Some have made the argument that the unique treatment of digital forms actually

\footnotetext{
118 Supra note 116.

119 John T. Holland, Making Money Instead of Excuses: A Market-Based Alternative to the Digital Millennium Copyright Act That Protects Copyrights Without Diminishing Expression, 7 GEO. J.L. \& PUB. POL'Y 279, 293 (2009)

${ }^{120}$ Donald P. Harris, The New Prohibition: A Look at the Copyright Wars Through the Lens of Alcohol Prohibition, 80 TenN. L. ReV. 101 (2012); Michael Kozlowski, EBook Pirates - The Reasons Why People Do It, GoOD E READER (Jan. 26, 2012), https://goodereader.com/blog/e-book-news/ebook-pirates-the-reasons-why-people-do-it ; Katy Guest, 'I can get any novel I want in 30 seconds': Can Book Piracy Be Stopped?, THE GUARDIAN (Mar. 6,
} 
increases piracy, broadly defined, where the actors are either frustrated at not being able to acquire a legitimate copy or are determined to be able to make what arguably is a fair use of the title. $^{121}$

There is simply no way to stop pirates, and pirating is done regardless of form. ${ }^{122}$ In many cases, the source for pirated copies are actually hard copies of materials - scanned-in print books, music ripped from CDs, movies ripped from DVDs or filmed live in theaters. ${ }^{123}$ Treating the digital copy of the work as more vulnerable than the physical copy ignores the reality.

That said, studies have shown that piracy generally drops when reasonably-priced, legitimate digital copies are readily available. ${ }^{124}$ And technologies such as blockchain or digital watermarking have been developed that arguably would do a better job at controlling or identifying misuse of copyrighted works than any legislation could. Today, there are much more effective mechanisms to encourage respect for copyright's principles than lawmaking. In such an environment, is it really in society's interest that a buyer of a print book can legally reconvey it but that a buyer of the same content in electronic format cannot?

First sale should apply to all formats, and as long as the number of copies on the market have not increased from the number legitimately authorized (or made under copyright exceptions), infringement should not apply. It is true that relying on detection of infringement is difficult, but one would argue that it is actually easier to detect infringing activity on digital works than it is on print works. One could fairly easily make copies of physical items and resell them under the radar, offline. ${ }^{125}$ Reselling items online often leaves digital footprints and tracking can be automated. Depending on the tools used to scan or reproduce copies, the copies may well hold personal information on the user and their location, information that would make it possible for the copyright owner to investigate. The same cannot be said about physical copies of books. Once made and distributed, they are unlikely to contain any identifying characteristics leading back to the infringer. Similarly, digital watermarks could be used to see how many copies are being generated from a single original copy. While privacy issues would need to be addressed with the use of these technologies, each seems to hold more promise than the DMCA

2019), https://www.theguardian.com/books/2019/mar/06/i-can-get-any-novel-i-want-in-30-seconds-can-bookpiracy-be-stopped.

${ }^{121}$ Harris, supra note 120 at 134-5.

${ }^{122} \mathrm{An}$ account from a book pirate that details both scanning in print books as well as breaking DRM, noting that most of the pirated copies he sees are scanned print copies, can be found at

https://themillions.com/2010/01/confessions-of-a-book-pirate.html (last visited, July 10, 2021).

${ }^{123}$ See earlier source - confessions of a pirate

${ }^{124}$ Brett Danaher et al., Converting Pirates Without Cannibalizing Purchasers: The Impact of Digital Distribution on Physical Sales and Internet Piracy, 29 MARKETING SCIENCE 1138 (2010) (describing two studies, one of music on iTunes and the other of television programs available through NBC or Hulu, showing more unauthorized copying when legal access was temporarily disrupted. Once the content became legally available again, unauthorized downloads went down, further illustrating that that paid content could compete with free.).

${ }^{125}$ WITT, supra note 33. 
or similar legislation. Last, technologies like blockchain or CDL can be used to create secure chains of conveyance similar to what is seen with analog items. ${ }^{126}$

\section{State Legislation}

Interestingly enough, the unique conditions of the pandemic brought to light many of copyright's imbalances, so much so that some states felt obliged to step in. When libraries and schools became physically unavailable but some publishers still refused to license e-books to libraries, states realized that the public interest was inadequately safeguarded by Congress and they contemplated action of their own. To avoid preemption challenges, these states targeted contracting rights - rights that fall squarely to the states - instead of directly invoking copyright.

At least three states (Maryland, Rhode Island, and New York) have proposed legislation requiring that publishers license e-materials to libraries if they already license those titles to the general public. ${ }^{127}$ Specific language from each state is below:

Maryland:

A publisher who offers to license and electronic literary product to the public also shall offer to license the electronic literary product to public libraries in the state on reasonable terms that would enable public libraries to provide library users with access to the electronic literary product. ${ }^{128}$

Rhode Island:

6-58-2. License to libraries and schools.

Any publisher who offers a contract or license for acquisition of electronic books and digital audiobooks to the public shall offer to license such books to libraries and to elementary and secondary schools and educational institutions in the state on reasonable terms that would permit the libraries, schools and educational institutions to provide their users and students with access to such electronic books. ${ }^{129}$

New York:

\footnotetext{
${ }^{126}$ Bill Rosenblatt, Can Blockchain Disrupt The E-Book Market? Two Startups Will Find Out, FORBES (Apr. 18, 2018), https://www.forbes.com/sites/billrosenblatt/2018/08/18/can-blockchains-disrupt-the-e-book-market-twostartups-will-find-out.

${ }^{127}$ If interested in more information on these state efforts, Library Futures (https://www.libraryfutures.net/) has been closely involved in each of these legislative developments and is tracking any new legislation.

${ }_{128}$ Maryland House Bill 0518 (2021), https://mgaleg.maryland.gov/mgawebsite/Legislation/Details/hb0518.

1292021 Rhode Island House Bill No. 6246, http://webserver.rilin.state.ri.us/BillText/BillText21/HouseText21/H6246.pdf.
} 
Any publisher who offers to license electronic books to the public shall offer to license such books to libraries in the state on reasonable terms that would permit the libraries to provide their users with access to such electronic books. ${ }^{130}$

In all three states, there is bipartisan support, and in Maryland, the bill passed both chambers unanimously. As each bill sits in different phases in their respective legislative processes, the effectiveness of such laws is yet to be known. Each known bill seeks more equitable access to information via libraries than is available today, but they also have significant deficiencies.

All use "reasonableness" as a standard without an objective test, so litigation will be necessary to test its contours. Any benefits may be long delayed depending on how willing Industry Conglomerates are to set high prices and how willing libraries will be to sue for compliance where the outcome is uncertain. Hypothetically, is it reasonable to charge libraries three times the cost to individuals? Five times? Ten times? And will libraries, who have no funds for litigation, sue to challenge a specific publisher's cost as reasonable especially if accepting the license cost is less expensive in the short-term?

Unfortunately, even under the most favorable application, all these legislative texts do is address a subset of harms, failing to close off the additional avenues publishers have already used in limiting access to these works (e.g., limits on number of uses). And, of course, even if these states are successful in their efforts, that success is necessarily limited only to the states that enact such legislation. There is no protection for the nation's public interest without action by Congress or our courts.

\section{Regulation or Private Litigation}

Suggested actions for Congress were covered in an earlier subsection, so this subsection looks to independent pathways through administrative offices or the courts include using preemption, misuse, or antitrust to invalidate contract provisions that use copyright to undermine its intended public interests. ${ }^{131}$ Of these, only antitrust has thus far garnered the attention of the federal government. ${ }^{132}$ Each argument, like the state efforts above, targets only the public interests

\footnotetext{
${ }^{130}$ New York Senate Bill 2890 (2021), https://www.nysenate.gov/legislation/bills/2021/s2890

${ }^{131}$ Michelle M. Wu, Restoring the Balance of Copyright: Antitrust, Misuse, and Other Possible Paths to Challenge Inequitable Licensing Practices (forthcoming LAW LIBRARY JOURNAL). Preliminary draft available at https://papers.ssrn.com/sol3/papers.cfm?abstract_id=3811707

132 Publishers have been hit by various antitrust suits, ranging from price fixing to discriminatory pricing. Andrew Albanese, Amazon, Big Five Publishers Face Yet Another Antitrust Suit-From Booksellers, Publishers Weekly (Mar. 26, 2021), https://www.publishersweekly.com/pw/by-topic/industry-news/publisher-news/article/85909amazon-big-five-publishers-face-yet-another-antitrust-suit-from-booksellers.html; AM. LIBRARY ASS'N, supra note 48.
} 
reached through libraries and not other harms caused by publisher practice (e.g., elimination of first sale). Each argument is set forth in brief below.

The preemption approach looks only to library licenses that seek to replace what historically has been met through ownership (i.e., buying a book). Preemption would apply only to nullify license terms that interfere with the exceptions to copyright found in sections 107 (fair use), 108 (preservation and interlibrary loan), and 109 (lending) of the copyright code.

In relation to copyright, the scope of preemption as outlined in 17 U.S.C. $\S 301$ asks if the work(s) in dispute falls within the subject matter of copyright $(\$ \S 102,103)$ and if the claimed right(s) is within the rights ( $\$ 106)$ that a copyright owner has been granted. If the answer to both questions is in the affirmative, then state action on that right is preempted. As applied to publisher-library licenses, preemption could be used to challenge clauses that limit the ability to exercise the exceptions to copyright contained in $\S \S 107-109$. These exceptions contain public interest rights that are as meaningful as the rights that have been granted to the copyright owner.

How might a preemption claim work in practice? Any attempt would focus on specific licensing terms (i.e., those that prohibit lending, interlibrary loan, preservation, or fair use), unequal bargaining power, and would demonstrate how the terms trespass on Congress' authority to determine copyright rights and restrictions. Congress chose to effect copyright in a particular way that these license terms override, and this transparent attempt to negate public rights should translate into the invalidity of the relevant license terms.

The antitrust angle is the most complicated of the three approaches mentioned but also may be the easiest to win because of the hard data that is available for analysis. The American Library Association's Competition in Digital Markets outlines the following anticompetitive behaviors by book publishers: refusal to make products available to libraries at any price (Amazon), delayed sales to libraries (Macmillan), abusive and discriminatory pricing (Simon \& Schuster), leases for private use only (Netflix, Spotify), prohibition on preservation activities, publisher consolidation leading to $45 \%$ of market power (presumptively illegal under Clayton Act), pricing that outstrips inflation, bundling (e.g., Big Deals), unfair bargaining power due to non-substitutable goods, and using market power to breach privacy. ${ }^{133}$ SPARC, in opposing the merger between Cengage and McGraw-Hill, adds weight to these anticompetitive claims specifically in the textbook market and raises additional questions about publishers elevating prices to make up for reduced sales, suppressing secondary markets, engaging in unfair pricing, coordinating price increases harmful to consumers, and privacy. ${ }^{134}$

The third avenue, misuse, is related to antitrust in that the elements of misuse are closely aligned with antitrust claims of refusal to deal, unreasonable restraint on trade, or illegal monopolistic conduct. However, misuse has a lower bar than antitrust so is offered as an alternative should the antitrust process prove to be too burdensome. Lasercomb v. Reynolds extrapolated from the patent misuse doctrine to develop the following description of copyright misuse:

\footnotetext{
133 AM. LIBRARY ASS'N, supra note 48.

${ }^{134}$ SPARC, supra note 48.
} 
The grant to the [author] of the special privilege of a [copyright] carries out a public policy adopted by the Constitution and laws of the United States, "to promote the Progress of Science and useful Arts, by securing for limited Times to [Authors] ... the exclusive Right ..." to their ["original" works]. United States Constitution, Art. I, § 8, cl. 8, [17 U.S.C.A. § 102]. But the public policy which includes [original works] within the granted monopoly excludes from it all that is not embraced in the [original expression]. It equally forbids the use of the [copyright] to secure an exclusive right or limited monopoly not granted by the [Copyright] Office and which it is contrary to public policy to grant. ${ }^{135}$ (emphasis added)

As licenses are mechanisms protecting copyright works in a manner not intended by the Copyright Act, the misuse argument would be used to force publishers to license e-books to libraries.

Unfortunately, these attempts, even if successful, are limited in application or will take such a long time to resolve that a great deal of harm will occur before resolution. An antitrust ruling determining that any of the listed practices are illegal would send a message to the relevant industry, but antitrust cases take on average three years to reach conclusion (before any appeal $)^{136}$. In other litigation, the ruling typically applies only to the parties involved. While others may be able to benefit from stare decisis in later cases, that boon accrues only if the new parties are willing to sue. It is, of course, possible that a ruling results in widespread change, especially on matters such as preemption, but the possibility of change will depend heavily on the facts of the case on which a court rules.

\section{Libraries Reassessing Risk}

As libraries and their communities have paid a disproportionate price under publisher practices, it should come as no surprise that many of them have concluded that they need to develop effective counter measures to retain the historic balance of copyright. Just as the pandemic moved states to action, it similarly animated libraries.

Prior to the pandemic, the risk for libraries in copyright innovation lay in the potential of litigation, both in terms of time and money, and most libraries determined that taking on any risk that endangered their ability to meet their primary missions was unwise. Any undertaking that

\footnotetext{
${ }^{135}$ Lasercomb Am., Inc. v. Reynolds, 911 F.2d 970, 977 (4th Cir. 1990).

136 Baker and McKenzie Blog, Competition Litigation in the United States, https://www.globalcompliancenews.com/antitrust-and-competition/competition-litigation/competition-litigation-inthe-united-states/.
} 
siphoned off money from collections or staffing or time from services therefore was backburnered. It was not as if risks to preservation and access (e.g., natural disasters) were unknown, ${ }^{137}$ but they seemed distant or unlikely enough at an individual-library level that addressing the risk was often not a high priority as compared to the endless immediate needs of their communities.

And then, suddenly, every library in the nation closed because of the coronavirus. The collections that libraries had spent billions to build were largely unavailable to their users at a time when those collections were most needed, both for education and entertainment. Through the lens of the pandemic, some libraries realized that taking strategic risks early equaled protections against future harms and accordingly, failing to take those risks meant no escape from harm when it fell.

Digitization serves as the example here, where an early, mass, collaborative and coordinated digitization effort could have ensured uninterrupted access to most resources for all of the nation's libraries and users even during a pandemic or nation-wide natural disaster. Libraries that engaged in digitization prior to the pandemic were able to maintain some access for their users, though none had had the resources to have had digitized their entire collections by the start of 2020. And no truly national, collaborative efforts had yet succeeded, though two arguably come close.

The first is the Internet Archive (IA), which was at the forefront of the CDL movement, having started to digitize and lend materials as early as $2010 .{ }^{138}$ By early 2020 , they had millions of titles digitized and still more in the pipeline. Even though they had encouraged collaboration, and had long provided tools for libraries and publishers to enable collaboration, the number of true collaborators, those that not only used IA's Open Library but contributed to them as well, was relatively small until recently. When the pandemic hit, many more libraries were interested and willing to be full participants.

The second example is HathiTrust. The core digital collections in HathiTrust were provided by the libraries that had partnered with Google on their Google Books Project early on, though many additional collections have been added since its inception. ${ }^{139}$ Until the start of the pandemic, use of the collection was greatly restricted. It allowed three uses: (1) anyone could search the materials full-text, with results returning the titles and page numbers on which the terms were found; (2) certified print disabled users could gain access to the full text; and (3) any member library who owned a copy of the work could use a full-text copy as a replacement copy under the same principles as articulated in 17 USC $108 .{ }^{140}$ Since the start of the pandemic,

\footnotetext{
137 Anna Gooding-Call, Disasters in Libraries, AMERICAN LIBRARIES (June 1, 2020), https://americanlibrariesmagazine.org/2020/06/01/disasters-in-libraries/; RICHARD KURIN, SAVING HAITI'S HERITAGE: CULTURAL RECOVERY AFTER THE EARTHQUAKE (2011), https://haiti.si.edu/docs/saving_haitis_heritage_book.pdf

${ }^{138}$ Internet Archive Blog, Digital Lending Library (June 28, 2010), http://blog.archive.org/2010/06/28/digitallending-library/

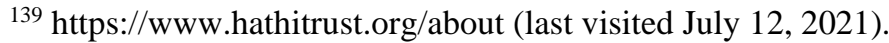

${ }^{140}$ Authors Guild, Inc. v. HathiTrust, 755 F.3d 87, 91 (2d Cir. 2014).
} 
though, HathiTrust implemented what they called an Emergency Temporary Access Service (ETAS), which in function mirrors the principles of CDL. ${ }^{141}$ Through ETAS, all member libraries were able to access full-texts of works that their libraries owned in print. As evidenced by the title, this service is intended only to be temporary, and applies only to "member libraries that have experienced unexpected or involuntary, temporary disruption to normal operations, requiring it to be closed to the public, or otherwise restrict collection access services." 142

Libraries that had not participated in CDL and were not interested in using the resources above had little access to copyrighted online works other than what they could afford to pay publishers for licenses to current e-books. ${ }^{143}$ Even then, licensing was not a particularly useful solution even for the wealthiest libraries, as the majority of titles in library collections do not exist in publisher-provided digital form anywhere.

Once the pandemic hit, many libraries, even those who had earlier been concerned about risk, pivoted to adopt CDL, whether only for a narrow purpose (e.g., course reserves) or for their full collections. Where staff were permitted to enter their facilities, even if patrons continued to be prohibited, digitization workflows for CDL were rapidly developed and implemented. Prior to the pandemic, there had primarily been a single platform for CDL - Adobe Digital Editions. Once more libraries invested in the outcome, dozens of possible alternatives came to light, some from modified existing document repository platforms (e.g., Google drive) and new ones from library vendors (e.g., ImageAccess). Libraries developed both manual and automated ways to ensure that lent items were locked down appropriately so that only a single user could use a title at any given time.

Collaborative taskforces have since cropped up nationwide, both within existing consortia (e.g., Virginia Academic Library Consortium) ${ }^{144}$ as well as in newly created groups (e.g., Controlled Digital Lending Implementers) ${ }^{145}$. Even as libraries reopen, these efforts to pursue CDL are intensifying, indicating a true shift in the view of risk for libraries. Developing a measured approach to risk (and then taking action in accordance with such a plan) may ultimately serve as the most effectively way to retain the balance of copyright, as it can serve as a persistent reminder to Industry Conglomerates that the public interest is not without advocates willing to fight for their rights under the Constitution.

\section{Conclusion}

\footnotetext{
${ }^{141}$ HathiTrust Response to Covid-19, https://www.hathitrust.org/covid-19-response (last visited July 12, 2021).

$142 \mathrm{https}$ //www.hathitrust.org/ETAS-Description (last visited July 12, 2021).

${ }^{143}$ It should be noted, particularly in academia, that many publishers did make their digital titles available for free, at least through the end of the spring semester 2020.

${ }^{144}$ Virginia's Academic Library Consortium, Joint Controlled Digital Lending Task Force, https://vivalib.org/va/resourcesharing/cdl-task-force (last visited July 12, 2021).

145 Controlled Digital Lending Implementers Forum, https://projectreshare.org/2020/09/30/controlled-digitallending-implementers-cdli-forum/ (last visited July 12, 2021).
} 
Across the board, every Industry Conglomerates action described in this paper harms all communities. The damage is not equally borne, though, as every instance of limiting access to information affects poorer communities more than they do wealthy ones and future generations more than current ones, increasing the nation's existing inequality divide. By building strategies on profit, and undermining dissemination and preservation, publishers have disrupted copyright's purpose and have done so in a way that has not just held the public interest in check but has actively harmed it.

With first sale eliminated, one cannot donate or sell materials at lower costs to people or libraries unable to afford the initial price; society will only be able to retain access to works as long as they can afford to pay repeatedly for the same content; and there is no guarantee that any information available through licensing will exist beyond today.

While profit is normally a justifiable business reason for decision-making, it should come under greater scrutiny when copyright is used for that profit, as the private grant of copyright is conditioned on the public good. When profit undermines that public purpose, Congress has the right and obligation to revoke the grant or take remedial steps to restore the public good. Where Congress fails to act, states, public institutions, and the public generally must take up the fight in their stead. In the past, this type of uncoordinated, multi-directional pressure has been successful to overcome the seemingly insurmountable obstacles erected to public benefit by self-interested, profit-driven industries. ${ }^{146}$ Without that vigilance and constant pressure, the balance of copyright will continue to be undermined with the majority of society paying a long-term price for its inattention.

\footnotetext{
146 Siddhartha MuKherJee, The EMPEROR OF All MAladies: A BIOGRAPHY OF CANCER 250-275 (Scribner, 2010). In his chapters about lung cancer and the tobacco industries, Mukherjee describes how cigarette makers leveraged their money, power, and influence over decades to suppress regulation and minimize legislation that would have exposed its products' cancer-causing effects. He then shows how private litigation, state action, and non-profit efforts --- all undertaken independently in hopes of holding the industry accountable for its deception, decreasing the incidence of cancer by smoking, or addressing the costs of care of such patients - in aggregate caused course correction even where government action had been long blockaded. No one action could claim to be the turning point; it was the incessant attack from all directions that ultimately produced sufficient data and public outrage to flip the story. (Well, to flip it in the United States. Sadly, the same companies took their old practices abroad where there were no developed safeguards against them.)
} 